\title{
Dogs, cats, parasites, and humans in Brazil: opening the black box
}

\author{
Filipe Dantas-Torres ${ }^{1,2^{*}}$ and Domenico Otranto ${ }^{2}$ \\ Portuguese version: Please see Additional file 1 (http://www.biomedcentral.com/content/supplementary/1756-3305-7-22-S1.pdf) \\ for the Portuguese version of this review article.
}

\begin{abstract}
Dogs and cats in Brazil serve as primary hosts for a considerable number of parasites, which may affect their health and wellbeing. These may include endoparasites (e.g., protozoa, cestodes, trematodes, and nematodes) and ectoparasites (i.e., fleas, lice, mites, and ticks). While some dog and cat parasites are highly host-specific (e.g., Aelurostrongylus abstrusus and Felicola subrostratus for cats, and Angiostrongylus vasorum and Trichodectes canis for dogs), others may easily switch to other hosts, including humans. In fact, several dog and cat parasites (e.g., Toxoplasma gondii, Dipylidium caninum, Ancylostoma caninum, Strongyloides stercoralis, and Toxocara canis) are important not only from a veterinary perspective but also from a medical standpoint. In addition, some of them (e.g., Lynxacarus radovskyi on cats and Rangelia vitalii in dogs) are little known to most veterinary practitioners working in Brazil. This article is a compendium on dog and cat parasites in Brazil and a call for a One Health approach towards a better management of some of these parasites, which may potentially affect humans. Practical aspects related to the diagnosis, treatment, and control of parasitic diseases of dogs and cats in Brazil are discussed.
\end{abstract}

Keywords: Dogs, Cats, Humans, Zoonosis, Control, South America

\section{Introduction}

The word "parasite" (from Ancient Greek, parasitos: para $=$ beside, sitos $=$ food) means literally a person that eats at the table of another. In the figurative sense, corrupt politicians that make the use their political power and public resources for their own benefit may be called parasites of society. But in parasitology, a parasite is an organism that takes benefit from another (the host), without giving something back and usually causing some damage to it. Incidentally, parasites constitute a diverse group of organisms that may affect a wide range of animal hosts, including amphibians, birds, fishes, mammals, and reptiles. They may be generally subdivided as endoparasites (=internal) and ectoparasites (=external), according to their location in the host. Ectoparasites may also be classified as permanent (e.g., lice and mites) or nonpermanent (e.g., ticks and mosquitoes), depending on the

\footnotetext{
* Correspondence: filipe.vet@globo.com
'Department of Immunology, Aggeu Magalhães Research Centre, Oswaldo

* Correspondence: filipe.vet@globo.com
'Department of Immunology, Aggeu Magalhães Research Centre, Oswaldo Cruz Foundation, Recife Pernambuco 50670420, Brazil

${ }^{2}$ Department of Veterinary Medicine, University of Bari, Valenzano 70010, Bari, Italy
}

relationship with their host; i.e., whether their life cycle takes place solely on their hosts or also in the environment.

Dogs and cats are the most popular pet animals worldwide. Nowadays, dogs for example have assumed many functions as guides for blind people, as therapeutic agents, as guard and hunting dogs. Moreover, in many developing countries, both dogs and cats have become part of human families, regardless of the social class (Figure 1). The benefits of having a pet animal are undisputed [1], but both dogs and cats may harbour many parasites potentially transmissible to humans, which may represent a health risk, especially to children, the elderly and the immunocompromised [2]. For instance, Toxoplasma gondii, Dipylidium caninum, Echinococcus granulosus, Ancylostoma braziliense, Toxocara canis, Onchocerca lupi, and Thelazia callipaeda are common parasites of dogs and cats that can affect humans in different countries around the world. This fact emphasizes the need for a One Health approach towards a more efficient management and control of these parasites [3,4].

At the beginning of the 21st century, parasitic diseases are still causing a severe burden on animal and human 


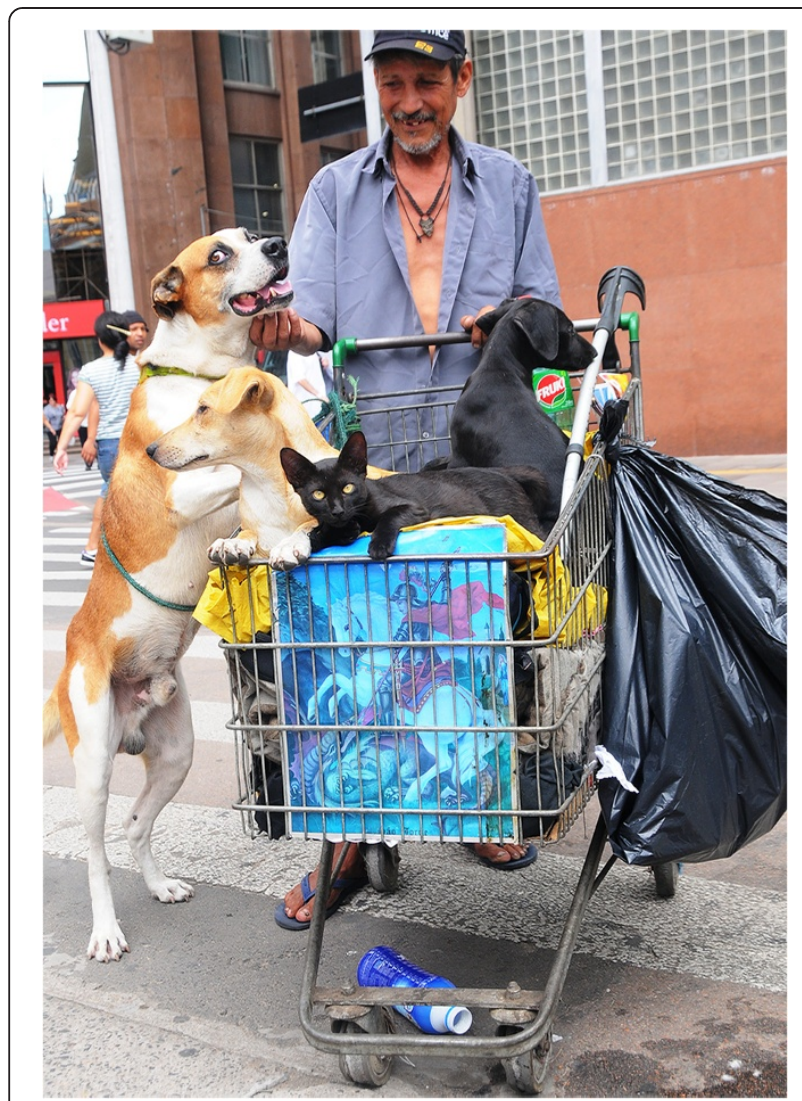

Figure 1 Human-animal bond. A homeless with his inseparable friends that were found abandoned in the streets of Porto Alegre, southern Brazil.

populations in tropical and subtropical regions around the world [5-7]. Furthermore, the impact of some of these diseases is disproportionally higher in developing countries such as Brazil, because the living conditions of the populations often favour the exposure to certain parasites, whose transmission may be associated with poor housing and sanitary conditions (Figure 2), as well as with inequities in the access to education and primary healthcare services.

Brazil is a country with continental dimensions (i.e., $8,515,767 \mathrm{~km}^{2}$ ), occupying most of the land area of South America and representing the largest economy in the region. Despite the persistent social and economic inequalities (e.g., unequal access to education, health care and sanitation, safe drinking water and decent housing), which have become the dark side of the Brazilian history, the importance of dogs and cats as pets, as well as the demand for high standard veterinary services, has increased over the last decades in Brazil. Impressively, according to the Associação Brasileira da Indústria de Produtos para Animais de Estimação (Abinpet), Brazil currently holds the world's second largest dog and cat populations, with over 37 million dogs and 21 million cats (http://abinpet.

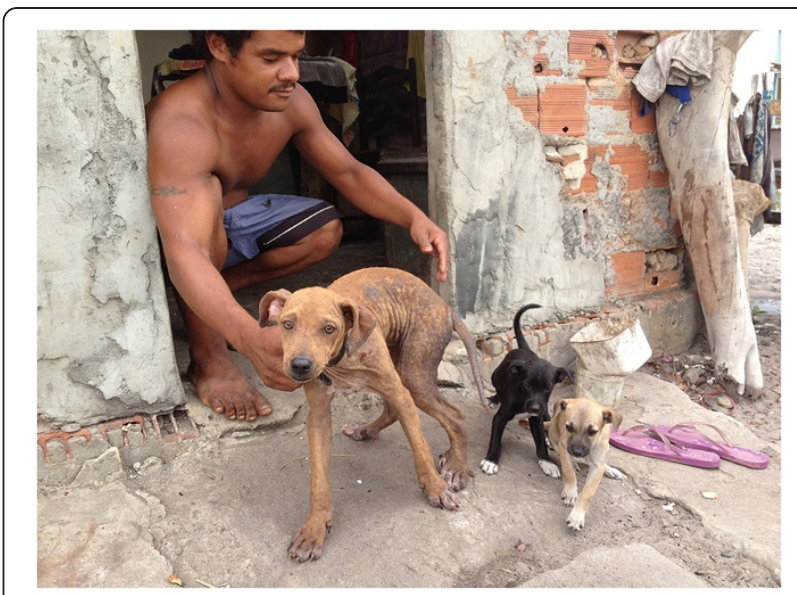

Figure 2 Poor living conditions. An owner and his dogs living in a poor rural community in Goiana, north-eastern Brazil, where visceral leishmaniosis is endemic. In poor rural communities people (as this man in the picture) are used to walking barefoot, which is a risk factor for bare feet-related diseases, such as cutaneous larva migrans and tungiasis.

org.br/imprensa/mercado-pet-deve-faturar-r-154-bilhoesem-2013). Apropos, the growing number of dogs and cats in urban areas in Brazil has been accompanied by substantial increases in the animal feed and pet care markets. According to Abinpet, the Brazilian pet market will earn 15.4 billion Brazilian real (approximately 7 billion US dollars) in 2013, with an overall increase of $8.3 \%$ in comparison with 2012. Specifically, it has been estimated that in 2013 the pet service sector (services related to animal care, including bath and hair cut) will increase in $24.5 \%$, pet food (animal feed) in 4.9\%, pet care (equipments, accessories and products for animal hygiene and care) in $5.2 \%$, and pet vet (medicines) in 6.7\%. These numbers pose Brazil as the world's second largest pet market, behind only the United States.

The diversity of natural environments present in Brazil is outstanding, as is its biodiversity. By the bye, dogs and cats living in Brazil may harbour a long list of parasites that may affect their wellbeing and eventually pose a risk to the health of their owners $[8,9]$. Information on their distribution, epidemiology, and impact on human health is fragmentary and mainly published in Brazilian journals. In this sense, this article is a compendium on dog and cat parasites in Brazil and a call for a One Health approach towards a better management of some of these parasites, which may potentially affect humans. Practical aspects related to the diagnosis, treatment, and control of parasitic diseases of dogs and cats in Brazil are discussed.

\section{Review}

\section{Ectoparasites of dogs and cats in Brazil}

Ectoparasites may cause irritation, blood depletion, pruritus, and skin lesions, potentially leading to the occurrence 
of secondary bacterial infections. Some ectoparasites such as fleas, lice and ticks may also transmit pathogens to dogs and cats, including bacteria, protozoa, and helminths reviewed in Ref. [9]. Furthermore, ticks can also cause toxicosis, as it has recently been reported in a dog bitten by the mouro tick Ornithodoros brasiliensis in Brazil [10].

In Brazil, dogs and cats may serve as hosts for a large number of ectoparasites, including fleas, lice, mites, and ticks (Tables 1 and 2). Indeed, dogs may be frequently infested by species of fleas (e.g., Ctenocephalides canis, Ctenocephalides felis felis, and Tunga penetrans), lice (e.g., Heterodoxus spiniger and Trichodectes canis), mites (e.g., Demodex canis, Otodectes cynotis, and Sarcoptes scabiei) and ticks (e.g., Amblyomma aureolatum, Amblyomma ovale, and Rhipicephalus sanguineus sensu lato) [11-41]. While some flea species may be common in rural settings (e.g., T. penetrans), C. felis felis is indeed the most common flea infesting dogs in Brazil. Other less common ectoparasites (e.g., the flea Rhopalopsyllus lutzi lutzi) have also been reported in dogs in Brazil $[21,28]$. In a similar manner, the findings of some wildlife-associated ticks (e.g., Amblyomma longirostre, Amblyomma naponsense, Amblyomma nodosum, Amblyomma pacae, Amblyomma scalpturatum, and Haemaphysalis juxtakochi) on dogs in Brazil are incidental findings and of unknown clinical significance.

Table 1 Ectoparasites of dogs in Brazil

\begin{tabular}{|c|c|c|c|c|}
\hline Phylum & Class & Order & Family & Species $^{a}$ \\
\hline \multirow[t]{31}{*}{ Arthropoda } & Arachnida & Ixodida & Argasidae & Ornithodoros brasiliensis \\
\hline & & & & Ornithodoros rostratus \\
\hline & & & Ixodidae & Amblyomma aureolatum \\
\hline & & & & Amblyomma cajennense \\
\hline & & & & Amblyomma longirostre \\
\hline & & & & Amblyomma naponsense \\
\hline & & & & Amblyomma nodosum \\
\hline & & & & Amblyomma oblongoguttatum \\
\hline & & & & Amblyomma ovale \\
\hline & & & & Amblyomma pacae \\
\hline & & & & Amblyomma parvum \\
\hline & & & & Amblyomma scalpturatum \\
\hline & & & & Amblyomma tigrinum \\
\hline & & & & Haemaphysalis juxtakochi \\
\hline & & & & Rhipicephalus microplus \\
\hline & & & & Rhipicephalus sanguineus s.l. \\
\hline & & Sarcoptiformes & Psoroptidae & Otodectes cynotis \\
\hline & & & Sarcoptidae & Notoedres cati \\
\hline & & & & Sarcoptes scabiei \\
\hline & & Trombidiformes & Demodicidae & Demodex canis \\
\hline & Insecta & Phthiraptera & Boopidae & Heterodoxus spiniger \\
\hline & & & Linognathidae & Linognathus setosus \\
\hline & & & Trichodectidae & Trichodectes canis \\
\hline & & Siphonaptera & Ceratophyllidae & Nosopsyllus fasciatus \\
\hline & & & Tungidae & Tunga penetrans \\
\hline & & & Pulicidae & Ctenocephalides canis \\
\hline & & & & Ctenocephalides felis felis \\
\hline & & & & Pulex irritans \\
\hline & & & & Xenopsylla brasiliensis \\
\hline & & & & Xenopsylla cheopis \\
\hline & & & Rhopalopsyllidae & Rhopalopsyllus lutzi lutzi \\
\hline
\end{tabular}


Table 2 Ectoparasites of cats in Brazil

\begin{tabular}{|c|c|c|c|c|}
\hline Phylum & Class & Order & Family & Species $^{\mathrm{a}}$ \\
\hline \multirow[t]{14}{*}{ Arthropoda } & Arachnida & Ixodida & Ixodidae & Amblyomma aureolatum \\
\hline & & & & Amblyomma ovale \\
\hline & & & & Amblyomma triste \\
\hline & & & & Rhipicephalus sanguineus s.l. \\
\hline & & Sarcoptiformes & Listrophoridae & Lynxacarus radovskyi \\
\hline & & & Psoroptidae & Otodectes cynotis \\
\hline & & & Sarcoptidae & Notoedres cati \\
\hline & & & & Sarcoptes scabiei \\
\hline & & Trombidiformes & Demodicidae & Demodex cati \\
\hline & Insecta & Phthiraptera & Trichodectidae & Felicola subrostratus \\
\hline & & Siphonaptera & Pulicidae & Ctenocephalides canis \\
\hline & & & & Ctenocephalides felis felis \\
\hline & & & & Pulex irritans \\
\hline & & & Tungidae & Tunga penetrans \\
\hline
\end{tabular}

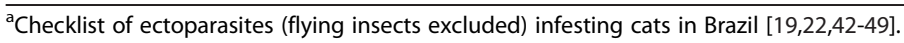

Cats in Brazil are frequently found infested by fleas (e.g., C. canis, C. felis felis, P. irritans, and T. penetrans), lice (Felicola subrostratus), and mites (e.g., D. cati, Lynxacarus radovskyi, Notoedres cati, and O. cynotis) [19,22,42-49]. Less frequently, they have been found infested by ticks such as $R$. sanguineus s.l. and Amblyomma triste [49,50]. Some of these ectoparasites are well known in certain regions (e.g., L. radovskyi in north-eastern Brazil), but completely unknown or considered rare in others. Even if cats have more knowhow than dogs when the issue is "ectoparasite removal" by grooming, they may be highly exposed to ectoparasites, particularly in high-density situations such as in catteries [45].

Even if most fleas, lice, mites, and ticks infesting dogs and cats may be easily identified, the delineation of some species may be troublesome for non-taxonomists [51,52]. While some keys for fleas, lice, and ticks have been published in books $[13,14,53]$ and journals [54-56], there are no comprehensive pictorial keys for the identification of dog and cat ectoparasites in Brazil (see Table 3 and Figure 3).

Flying insects may also represent a significant clinical problem to dogs as cats in Brazil [9,57-66]. For instance, mosquitoes, phlebotomine sand flies and triatomine bugs are vectors of Dirofilaria immitis, Leishmania infantum, and Trypanosoma cruzi, respectively, to both dogs and cats [9]. Myiasis is also quite a common problem in dogs and cats in Brazil, being most frequently associated with infestation by larvae of Cochliomyia hominivorax and Dermatobia hominis [58-65], and less commonly by other species of flies (e.g., Lucilia eximia) [57,65]. Furthermore, stable flies (Stomoxys calcitrans) can produce skin lesions on the ears of these animals, which may also lead to the occurrence of secondary bacterial infections $[9,66]$.

\section{Endoparasites of dogs and cats in Brazil}

In addition to ectoparasites, dogs in Brazil may be affected by numerous endoparasites (Table 4), including protozoa, cestodes (tapeworms), trematodes (flukes), and nematodes (roundworms) [32,67-130]. For instance, endoparasites such as Dipylidium caninum, Echinococcus granulosus, A. braziliense, Ancylostoma caninum, Strongyloides stercoralis, Toxocara canis, Trichuris vulpis, and Dirofilaria immitis are commonly found in dogs from different Brazilian regions $[67,69]$. Other endoparasites such as Angiostrongylus vasorum have only sporadically been reported in Brazil [74]. Similarly, cats have frequently been found affected by several endoparasites (Table 5) in Brazil, including T. gondii, D. caninum, Taenia taeniformis, Spirometra mansonoides, Aelurostrongylus abstrusus, A. braziliense, A. caninum, A. tubaeforme, Toxascaris leonina, Toxocara cati, Pearsonema feliscati, Trichuris campanula, Trichuris serrata, Physaloptera praeputialis, and Platynosomum fastosum $[47,71,87,90,92,97,131-137]$. Less common endoparasites have also been reported in cats, such as the acanthocephalan Sphaerirostris erraticus [137].

Dogs have been found infected by vector-borne protozoa, including Babesia gibsoni, Babesia vogeli, Rangelia vitalii, Hepatozoon canis, Leishmania amazonensis, Leishmania braziliensis, Leishmania infantum, Trypanosoma cruzi, and Trypanosoma evansi $[73,78-82,85,87-90,96,102-$ $104,109-113,117-121,124,128-130]$. Other protozoa of unknown pathogenicity (e.g., Trypanosoma caninum) have also been described in Brazilian dogs [108]. In addition, other vector-borne organisms have also been frequently reported in dogs, including Anaplasma platys, Ehrlichia canis and, less frequently, Rickettsia rickettsii [9].

Cats have also been found infected by vector-borne protozoa such as B. vogeli, Cytauxzoon felis, H. canis, 
Table 3 Key for ectoparasites identification

\begin{tabular}{|c|c|c|}
\hline $1 a$ & Three pairs of legs & 2 \\
\hline $1 b$ & Four pairs of legs & 13 \\
\hline $2 a$ & Body laterally flattened (SIPHONAPTERA) & 3 \\
\hline $2 b$ & Body dorsoventrally flattened (PHTHIRAPTERA) & 10 \\
\hline $3 a$ & Pronotal and/or genal ctenidia present & 4 \\
\hline $3 b$ & Pronotal and genal ctenidia absent & 6 \\
\hline $4 a$ & Genal ctenidium absent and pronotal ctenidium present & Nosopsyllus fasciatus \\
\hline $4 \mathrm{~b}$ & Genal and pronotal ctenidia present & 5 \\
\hline $5 a$ & $\begin{array}{l}\text { Genal ctenidium with the first seta much shorter than the others (Figure 3A; arrowhead); posterior tibia with two } \\
\text { simple setae between the penultimate and the last double setae (Figure 3A; arrows) }\end{array}$ & Ctenocephalides canis \\
\hline $5 b$ & $\begin{array}{l}\text { Genal ctenidium with the first seta approximately the same length of the remaining (Figure 3B; arrowhead); } \\
\text { posterior tibia with one simple seta between the penultimate and the last double setae (Figure 3B; arrow) }\end{array}$ & Ctenocephalides felis feli \\
\hline $6 a$ & $\begin{array}{l}\text { Thoracic segments narrow (Figure 3C; arrow), ocular and occipital setae absent; front of the head angular } \\
\text { (upturned) (Figure 3C; arrowhead) }\end{array}$ & Tunga penetrans \\
\hline $6 b$ & Not as above & 7 \\
\hline $7 a$ & Abdominal segments with two rows of setae in the dorsal border & Rhopalopsyllus lutzi lutzi \\
\hline $7 b$ & Abdominal segments with one row of setae in the dorsal border & 8 \\
\hline $8 a$ & Occipital region with one seta (Figure 3D; arrow) & Pulex irritans \\
\hline $8 b$ & Occipital region with two rows of setae arranged in a " $\mathrm{V}$ " & 9 \\
\hline $9 a$ & $\begin{array}{l}\text { Male antepygidial seta inserted on a discrete tubercle; female with body of spermatheca (in black) not larger than } \\
\text { the base of tail (Figure 3E) }\end{array}$ & Xenopsylla cheopis \\
\hline $9 b$ & $\begin{array}{l}\text { Male antepygidial seta inserted on a well-developed tubercle; female with body of spermatheca (in black) larger } \\
\text { than the base of tail (Figure } 3 \mathrm{~F} \text { ) }\end{array}$ & Xenopsylla brasiliensis \\
\hline $10 \mathrm{a}$ & Head longer than large (Figure 3G; arrow); sucking mouthparts & Linognathus setosus \\
\hline $10 \mathrm{~b}$ & Head as large as long; chewing mouthparts & 11 \\
\hline $11 a$ & Tarsus with two claws (Figure $3 \mathrm{H}$; arrow) & Heterodoxus spiniger \\
\hline $11 b$ & Tarsus with one claw & 12 \\
\hline $12 \mathrm{a}$ & Head rounded anteriorly (Figure 31) & Trichodectes canis \\
\hline $12 \mathrm{~b}$ & Head triangular in shape (Figure 3J) & Felicola subrostratus \\
\hline $13 a$ & Body length equal or less than $0.5 \mathrm{~mm}$; Haller's organ absent & 14 \\
\hline $13 b$ & Body length larger than $0.5 \mathrm{~mm}$; Haller's organ present on first tarsi (IXODIDA) & 19 \\
\hline $14 a$ & Body carrot-shaped or with a bell pepper shape (TROMBIDIFORMES) & 15 \\
\hline $14 \mathrm{~b}$ & Body not as above, usually rounded in shape (SARCOPTIFORMES) & 16 \\
\hline $15 \mathrm{a}$ & Body long and slender (carrot-shaped) (Figure 3K) & Demodex spp. ${ }^{a}$ \\
\hline $15 b$ & Body with a bell pepper shape; well-developed mouthparts; palpi that end in prominent hooks (Figure 3L; arrow) & Cheyletiella spp. ${ }^{\mathrm{b}}$ \\
\hline $16 a$ & Body rounded & 17 \\
\hline $16 b$ & Body cylindrical and elongate, heavily striated (Figure 3M) & Lynxacarus radovskyi \\
\hline $17 \mathrm{a}$ & Legs long, with short, unjointed pedicels (Figure 3N) & Otodectes cynotis \\
\hline $17 b$ & Legs short, with long, unjointed pedicels & 18 \\
\hline $18 \mathrm{a}$ & Anus dorsal (Figure 30; arrow) & Notoedres cati \\
\hline $18 b$ & Anus terminal (Figure 3P; arrow); body surface covered by several triangular spines arranged in rows & Sarcoptes scabiei \\
\hline $19 a$ & Inornate; basis capituli hexagonal; coxa I bifid & $\begin{array}{l}\text { Rhipicephalus } \\
\text { sanguineus s.l.c }\end{array}$ \\
\hline $19 b$ & Usually ornate; basis capituli variable in form & Amblyomma spp. ${ }^{d}$ \\
\hline
\end{tabular}

${ }^{\mathrm{a}}$ Demodex canis in dogs and Demodex cati in cats.

${ }^{\mathrm{b}} \mathrm{No}$ bona fide data on Cheyletiella spp. in dogs or cats in Brazil.

'At least two distinct biologically and genetically distinct tick populations under the name " $R$. sanguineus" have been found on dogs in South America [52,161,162]. dSeveral species reported in dogs and cats. Amblyomma aureolatum, Amblyomma cajennense and Amblyomma ovale are among the most common Amblyomma species found on rural dogs in Brazil [55]. 


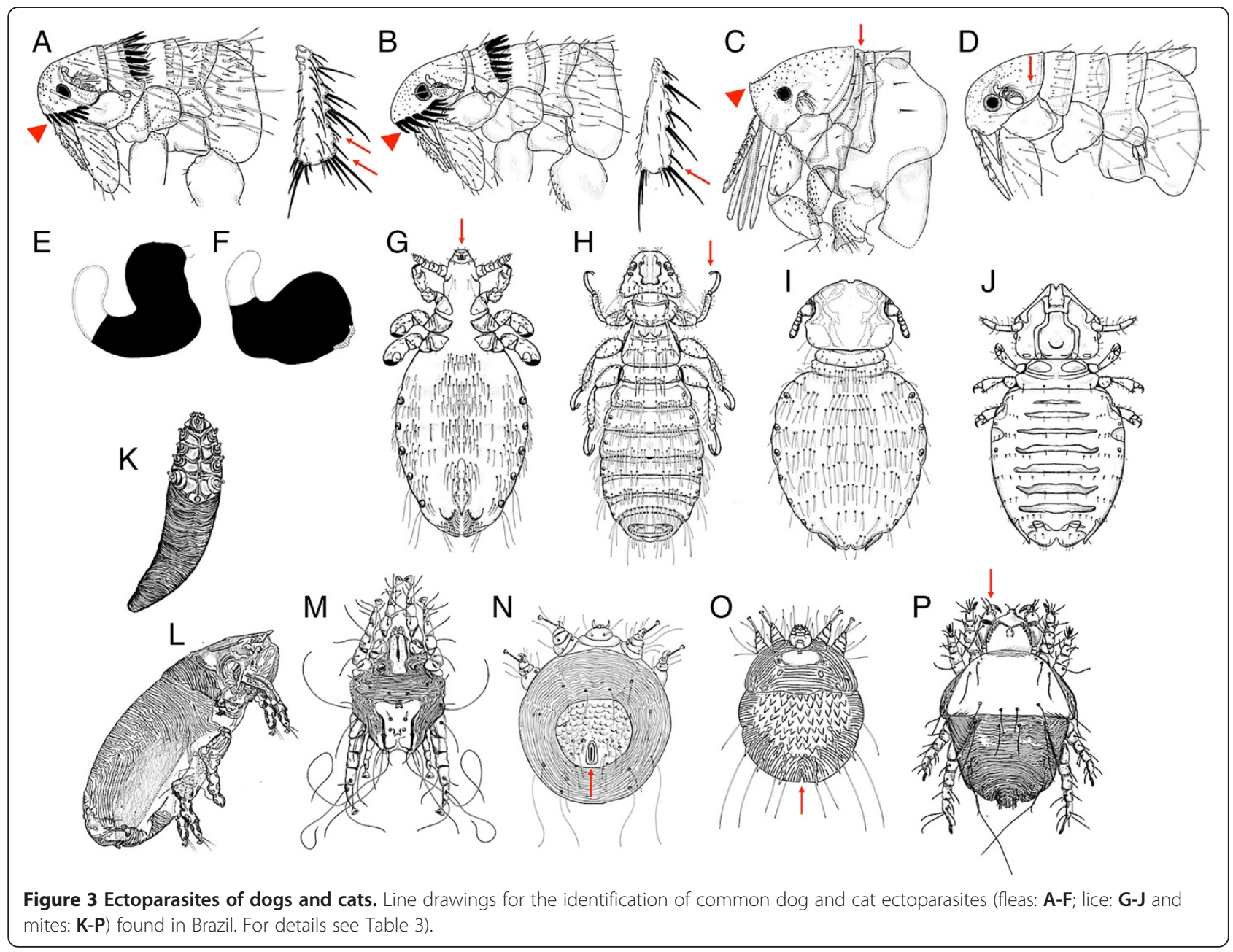

Hepatozoon felis, L. amazonensis, L. braziliensis, and L. infantum [42,44,129,136,138-148]. Indeed, the diversity of endoparasites of cats and dogs in Brazil is impressive, but certainly underestimated, mainly because most studies carried out in this country have been based on the detection and identification of eggs and oocysts in faecal samples using ordinary coprological techniques. This emphasizes the need for additional diagnostic methods (e.g., coproantigen tests, molecular tests or post-mortem examination) if we are to understand the actual diversity and prevalence of endoparasites of dogs and cats in Brazil.

\section{Geographical distribution and prevalence}

Dog and cat parasites are widespread in Brazil and in most cases occur virtually in all geographical regions (north, northeast, south, southeast, and centre-west) of the country. However, for several common external parasites (e.g., D. canis, N. cati e O. cynotis) and internal (e.g., D. caninum, A. brasiliense e T. canis) there is relatively limited published information, particularly in international journals. Therefore, it is presently difficult to generate informative, bona fide maps for most dog and cat parasites occurring in Brazil, even if most of these parasites are certainly present in all regions of the country. For instance, in a study carried out in south-eastern Brazil, 155 dogs were necropsied and D. caninum was diagnose in 57 (36.8\%) of them, A. caninum in 30 (19.4\%), and T. canis in 24 (15.5\%) [36]. Similarly, a study conducted in north-eastern Brazil, revealed that A. caninum (prevalence, 95.7\%) was the most prevalent endoparasite in 46 stray dogs necropsied, followed by $D$. caninum (45.7\%), T. canis (8.7\%), and T. vulpis (4.3\%) [32]. These studies indicate high prevalence rates of infestation by endoparasites in stray dogs from different Brazilian regions representing a permanent source of endoparasites to pet animals and a major zoonotic hazard for humans, through the contamination of public parks and beaches (see "Dogs, cats, parasites and humans: public health aspects").

Stray cats are also frequently exposed to endoparasites. For instance, a study conducted in south-eastern Brazil reported infestations by $A$. braziliense (67.3\%), A. caninum (21.1\%), and A tubaeforme (9.6\%) in 52 cats necropsied [116]. Similarly, in a recent study conducted in centre- 
Table 4 Endoparasites of dogs in Brazil

\begin{tabular}{|c|c|c|c|c|}
\hline Phylum & Class & Order & Family & Species $^{\mathrm{a}}$ \\
\hline \multirow[t]{14}{*}{ Apicomplexa } & Aconoidasida & Piroplasmida & Babesiidae & Babesia gibsoni \\
\hline & & & & Babesia vogeli \\
\hline & & & Theileriidae $^{b}$ & Rangelia vitalii \\
\hline & Conoidasida & Eucoccidiorida & Hepatozoidae & Hepatozoon canis \\
\hline & & & Cryptosporidiidae & Cryptosporidium canis \\
\hline & & & Eimeridae & Isospora canis (syn. Cystoisospora canis) \\
\hline & & & & Isospora ohioensis (syn. Cystoisospora ohioensis) \\
\hline & & & Sarcocystidae & Hammondia heydorni \\
\hline & & & & Neospora caninum \\
\hline & & & & Sarcocystis capracanis \\
\hline & & & & Sarcocystis cruzi (syn. Sarcocystis bovicanis) \\
\hline & & & & Sarcocystis levinei \\
\hline & & & & Sarcocystis miescheriana (syn. Sarcocystis suicanis) \\
\hline & & & & Sarcocystis tenella (syn. Sarcocystis ovicanis) \\
\hline Metamonada & Parabasalia & Trichomonadida & Trichomonadidae & Pentatrichomonas hominis (syn. Trichomonas hominis) \\
\hline \multirow[t]{7}{*}{ Sarcomastigophora } & Zoomastigophora & Diplomonadida & Hexamitidae & Giardia duodenalis (syn. Giardia intestinalis) \\
\hline & & Kinetoplastida & Trypanosomatidae & Leishmania infantum (syn. Leishmania chagasi) \\
\hline & & & & Leishmania amazonensis \\
\hline & & & & Leishmania braziliensis \\
\hline & & & & Trypanosoma caninum \\
\hline & & & & Trypanosoma evansi \\
\hline & & & & Trypanosoma cruzi \\
\hline \multirow[t]{17}{*}{ Nematoda } & Secernentea & Strongylida & Ancylostomatidae & Ancylostoma braziliense \\
\hline & & & & Ancylostoma caninum \\
\hline & & & Angiostrongylidae & Angiostrongylus vasorum \\
\hline & & Rhabditida & Strongyloididae & Strongyloides stercoralis \\
\hline & & Ascaridida & Ascarididae & Lagochilascaris minor \\
\hline & & & & Toxascaris leonina \\
\hline & & & & Toxocara canis \\
\hline & & & Dioctophymatidae & Dioctophyme renale \\
\hline & & Trichurida & Trichinellidae & Calodium hepaticum (syn. Capillaria hepatica) \\
\hline & & & Trichuridae & Trichuris vulpis \\
\hline & & Spirurida & Gongylonematidae & Gongylonema pulchrum \\
\hline & & & Onchocercidae & Acanthocheilonema reconditum \\
\hline & & & & Cercopithifilaria bainae \\
\hline & & & & Cercopithifilaria grassii (syn. Dipetalonema grassii) \\
\hline & & & & Dirofilaria immitis \\
\hline & & & Physalopteridae & Physaloptera praeputialis \\
\hline & & & Spirocercidae & Spirocerca lupi \\
\hline
\end{tabular}


Table 4 Endoparasites of dogs in Brazil (Continued)

\begin{tabular}{|c|c|c|c|c|}
\hline \multirow[t]{5}{*}{ Platyhelminthes } & Cestoda & Cyclophyllidea & Dipylidiidae & Dipylidium caninum \\
\hline & & & Taeniidae & Echinococcus granulosus \\
\hline & & & & Taenia hydatigena \\
\hline & & & & Taenia multiceps (syn. Multiceps multiceps) \\
\hline & Trematoda & Opisthorchiida & Heterophyidae & Ascocotyle longa (syn. Phagicola arnaldoi) \\
\hline Acanthocephala & Archiacanthocephala & Oligacanthorhynchida & Oligacanthorhynchidae & Oncicola canis \\
\hline
\end{tabular}

${ }^{a}$ Checklist of endoparasites (protozoa and helminths) affecting dogs in Brazil [32,67-130,344-353] Doubtful records (e.g., Phagicola minuta, Aelurostrongylus abstrusus, Dirofilaria repens, Necator americanus, Trichuris serrata, Uncinaria stenocephala, Isospora rivolta, and Isospora bigemina) [68,69] are not included. ${ }^{\mathrm{b}}$ The genus Rangelia has long been regarded a synonym of Babesia (family Babesiidae), but recent genetic and biological data supports its validity and its inclusion in the family Theileriidae. The creation of a monospecific family (Rangeliidae) does not seem desirable.

western Brazil, 146 cats were necropsied and 98 of them were infested by roundworms $[A$. braziliense (50.68\%); A. tubaeforme (10.27\%); T. cati (4.11\%); P. praeputialis (2.05\%); P. feliscati (3.42\%); and A. abstrusus (1.37\%)], cestodes [S. mansonoides (4.11\%); D. caninum (3.42\%); and T. taeniformis $(0.68 \%)]$, trematodes [P. fastosum $(26.03 \%)]$, and acanthocephalans [S. erraticus (3.42\%)] [137]. Again, these studies reveal a considerable diversity of endoparasites in cats from different Brazilian regions, with relatively high prevalence rates.

The geographical distribution of vector-borne protozoa and heminths of dogs has been reviewed elsewhere [9]. For instance, L. infantum is widespread in all Brazilian regions $[81,113,149,150]$, but less frequent in southern parts of the country $[151,152]$. However, L. longipalpis, the principal vector for $L$. infantum, is present in northern Argentina [153], Paraguay [154], and has recently been detected in Uruguay [155]. Furthermore, L. longipalpis is abundant in Mato Grosso do Sul State [156], which makes border with Paraná State in southern Brazil. Last but not least, the presence of $L$. longipalpis in Rio Grande do Sul (the southernmost Brazilian state) has been proven [157]. These findings may suggest that L. longipalpis may have already colonized other areas of southern Brazil and that canine leishmaniosis may become a problem in that region in the near future.

The little known protozoan $R$. vitalii occurs mainly in southern and south-eastern Brazil [119,124,158,159], where ticks such as $A$. aureolatum, the putative vector, are commonly found in dogs frequenting the Atlantic rainforest environment [160]. Interestingly, B. gibsoni has been reported exclusively in southern Brazil [87,104], which also suggests that $R$. sanguineus s.l. is not the vector of this protozoan in Brazil, considering that this tick is prevalent in virtually all regions of the country $[52,161,162]$. In fact, pathogens that are transmitted by R. sanguineus s.l. (e.g., B. vogeli and Ehrlichia canis) are usually widespread in Brazil [9], not concentrated in a specific region as it occurs with $B$. gibsoni. In any case, the possibility that $R$. sanguineus s.l. ticks are acting as vectors of B. gibsoni in Brazil cannot be ruled out.
Ctenocephalides spp. fleas are also widespread in Brazil $[18,35,36,38,129]$, but $C$. felis felis surpasses $C$. canis in distribution, the latter being reputed to be more common in regions with more temperate climates, as in the southeast and south of the country [51]. Indeed, C. felis felis has been reported in 17 states (Alagoas, Amazonas, Bahia, Ceará, Espírito Santo, Goiás, Mato Grosso, Minas Gerais, Paraíba, Paraná, Pernambuco, Rio de Janeiro, Rio Grande do Norte, Rio Grande do Sul, Roraima, Santa Catarina, and São Paulo), while C. canis has been reported in only nine (Amazonas, Bahia, Maranhão, Minas Gerais, Paraná, Pernambuco, Rio Grande do Sul, Santa Catarina, and São Paulo) [51]. As a consequence of the widespread distribution of Ctenocephalides spp. fleas on dogs and cats, flea-borne parasites like $D$. caninum and $A$. reconditum [163-167] are widespread in Brazil as reviewed in Ref. [9].

Even if fleas, lice and ticks may be found infesting dogs in all Brazilian regions, the distribution and prevalence at the local level may vary widely, also according to climate conditions and the degree of urbanization of each area. For instance, in a study conducted in north-eastern Brazil, the frequency of infestation by $R$. sanguineus s.l. tended to be higher in urban than in rural areas, whereas infestations by Amblyomma ticks and C. felis felis was more common on rural dogs [39]. In the same study, mixed infestations were significantly more frequent on rural than on urban dogs. Nonetheless, even if $R$. sanguineus s.l. ticks are more prevalent in urban settings $[18,28,32]$, they may infest a high proportion of rural dogs in some areas [30,33,36].

Serological surveys have also reported moderate to high levels of exposure to parasites such as Neospora caninum and T. gondii in dogs and cats in Brazil [151,168-173]. For instance, in a recent study carried out in south-eastern Brazil, 386 cats were assayed by indirect immunofluorescence antibody tests (IFAT) for the presence of antibodies against T. gondii and $63(16.3 \%)$ of them were positive [172]. Prevalence rates of anti- $N$. caninum antibodies in dogs ranging from $26 \%$ to $34.5 \%$ were reported in north-eastern Brazil, with $57.6 \%$ of the seropositive dogs also being positive for anti-T. gondii antibodies [169]. In 
Table 5 Endoparasites of cats in Brazil

\begin{tabular}{|c|c|c|c|c|}
\hline Phylum & Class & Order & Family & Species $^{a}$ \\
\hline \multirow[t]{5}{*}{ Sarcomastigophora } & Zoomastigophora & Diplomonadida & Hexamitidae & Giardia duodenalis \\
\hline & & Kinetoplastida & Trypanosomatidae & Leishmania infantum \\
\hline & & & & Leishmania amazonensis \\
\hline & & & & Leishmania braziliensis \\
\hline & & & & Trypanosoma cruzi \\
\hline \multirow[t]{10}{*}{ Apicomplexa } & Aconoidasida & Piroplasmida & Babesiidae & Babesia vogeli \\
\hline & & & Theileriidae & Cytauxzoon felis \\
\hline & Conoidasida & Eucoccidiorida & Hepatozoidae & Hepatozoon canis \\
\hline & & & & Hepatozoon felis \\
\hline & & & Cryptosporidiidae & Cryptosporidium felis \\
\hline & & & Eimeriidae & Isospora felis (syn. Cystoisospora felis) \\
\hline & & & & Isospora felis (syn. Cystoisospora rivolta) \\
\hline & & & Sarcocystidae & Hammondia hammondi \\
\hline & & & & Sarcocystis hirsuta (syn. Sarcocystis bovifelis) \\
\hline & & & & Toxoplasma gondii \\
\hline \multirow[t]{17}{*}{ Nematoda } & Secernentea & Strongylida & Ancylostomatidae & Ancylostoma braziliense \\
\hline & & & & Ancylostoma caninum \\
\hline & & & & Ancylostoma tubaeforme \\
\hline & & & Angiostrongylidae & Aelurostrongylus abstrusus \\
\hline & & & & Gurltia paralysans \\
\hline & & & Syngamidae & Mammomonogamus dispar \\
\hline & & Rhabditida & Strongyloididae & Strongyloides stercoralis \\
\hline & & Ascaridida & Ascarididae & Lagochilascaris minor \\
\hline & & & & Toxascaris leonina \\
\hline & & & & Toxocara cati (syn. Toxocara mistax) \\
\hline & & & Dioctophymatidae & Dioctophyme renale \\
\hline & & Trichurida & Capillariidae & Calodium hepaticum (syn. Capillaria hepatica) \\
\hline & & & & Pearsonema feliscati \\
\hline & & & Trichuridae & Trichuris campanula \\
\hline & & & & Trichuris serrata \\
\hline & & Spirurida & Onchocercidae & Dirofilaria immitis \\
\hline & & & Physalopteridae & Physaloptera praeputialis \\
\hline \multirow[t]{7}{*}{ Platyhelminthes } & Cestoda & Cyclophyllidea & Dipylidiidae & Dipylidium caninum \\
\hline & & & Taeniidae & Taenia taeniformis \\
\hline & & Pseudophyllidea & Diphyllobothriidae & Spirometra mansonoides \\
\hline & Trematoda & Opisthorchiida & Heterophyidae & Ascocotyle angrense \\
\hline & & & & Ascocotyle longa (syn. Phagicola arnaldoi) \\
\hline & & Plagiorchiida & Dicrocoeliidae & Platynosomum fastosum \\
\hline & & Strigeatida & Diplostomatidae & Alaria alata \\
\hline \multirow[t]{2}{*}{ Acanthocephala } & Archiacanthocephala & Moniliformida & Moniliformidae & Moniliformis moniliformis \\
\hline & Palaecanthocephala & Polymorphida & Centrorhynchidae & Sphaerirostris erraticus \\
\hline
\end{tabular}

${ }^{a}$ Checklist of endoparasites (protozoa and helminths) affecting cats in Brazil [42,44,47,71,87,90,92,97,129,131-148,346,349,352-356]. Doubtful records (e.g., Ascaridia galli and Heterakis gallinarum) $[68,69]$ are not included. 
another study conducted in south-eastern Brazil, 703 dogs from urban and rural areas were tested for $N$. caninum and $11.4 \%$ of them were positive. The likelihood of being positive to $N$. caninum was associated with dogs aged $>4$ years, guard dogs, hunting dogs, and with dogs from dairy farms with a history of bovine abortion [173]. In particular, among rural dogs, an association with seroprevalence was recorded for milk farms, dogs not fed with commercial food, hunting, and guard dogs. Altogether, these studies reveal that dogs and cats from different regions both rural and urban areas are at risk of infection by parasites such as $N$. caninum and T. gondii. This is also true for Leishmania spp. in dogs, for which seroprevalence rates higher than $60 \%$ have been reported in some highly endemic areas [168].

\section{Seasonal dynamics in the tropics}

Information on the ecology of parasites of dogs and cats in Brazil is fragmentary, meagre, and, for several parasites, completely lacking. Considering the variety of biomes (Atlantic Rainforest, Amazon, Pantanal, Cerrado, Caatinga, and Pampa) and climates (from tropical north to temperate zones below the Tropic of Capricorn) registered in Brazil, the seasonal dynamics of dog and cat parasite populations would be expectedly variable from region to region. Nonetheless, the climate conditions in Brazil are so suitable that a range of arthropod vectors are found the year-round. For instance, studies carried out in an area of D. immitis endemicity in Rio de Janeiro indicated that mosquito vectors (e.g., Ochlerotatus scapularis and Ochlerotatus taeniorhynchus) are more abundant during summer months, but may also be captured in high number in winter months [174]. These findings suggest that dogs and cats may be at risk of $D$. immitis infestation during the whole year, especially because the average annual temperature in most of the Brazilian territory is between 21 and $30^{\circ} \mathrm{C}$, which indeed facilitates the development of infective larvae (L3) in the mosquito vector.

The presence of ectoparasites during the whole year in Brazil is apparently the rule, not the exception. Phlebotomine sand fly vectors of Leishmania parasites such as L. longipalpis (Figure 4) and L. whitmani may be found in high numbers throughout the year in different Brazilian regions [175-180], even if some species may display population peaks during the months of highest rainfall [181]. The same applies for fleas and ticks. A recent study developed in south-eastern Brazil revealed high prevalence rates of flea ( $C$. felis felis) and tick $(A$. cajennense and $R$. sanguineus s.l.) infestations during the dry and rainy seasons [35]. Another study carried out in the same region indicated that $R$. sanguineus s.l. may infest dogs during any period of the year and completes three generations per year [182]. Similarly, an investigation conducted in centre-western Brazil suggested that this tick may complete up to four generations per year [183]. Again, these findings suggest that different Brazilian regions possess climate types and environmental conditions that enable the occurrence of ticks during all months of the year. For example, even if a study has identified variations in $B$. vogeli infection in dogs apparently associated with peaks in the tick vector population [184], evidence indicates that this protozoan may infect dogs at any period of the year in some regions, regardless of the season [120]. On the other hand, myiasis by C. hominivorax in dogs and cats presents a clearly defined seasonal pattern in Brazil, peaking during the hottest months of the year [59-61,65].

Data concerning the seasonal dynamics of endoparasites in dogs and cats in Brazil is meagre. The incidence of hookworm-related cutaneous larva migrans is higher during the rainy season [185]. Interestingly, a study reported a marked peak in Ancylostoma eggs shedding in dog faeces during summer and autumn, suggesting that winter conditions in São Paulo (south-eastern Brazil) have a negative effect on hookworm transmission [74]. Another study concluded that the southern region of Brazil has favourable edaphic and climatic conditions for soil contaminants (e.g., Toxocara eggs) to persist yearround, even if the species diversity of parasites was lower in winter and the number of parasites lower in summer [186]. This is in agreement with studies carried out in other parts of South America. For instance, a study conducted in Mar del Plata, Argentina, reported a high

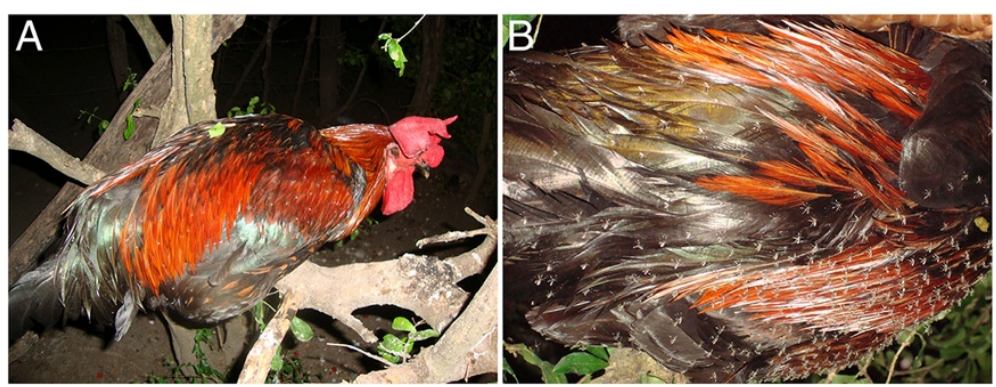

Figure 4 Vector density. Hundreds of phlebotomine sand flies (Lutzomyia longipalpis) on a chicken (A) that was resting on a tree trunk in Passira, north-eastern Brazil, where visceral leishmaniosis is endemic. (B) shows a close-up of the phlebotomine sand flies 
prevalence of intestinal parasites of dogs throughout the year, with some seasonal variations according to the genus or species of parasite [187]. Hookworms (Ancylostoma spp.) were more prevalent in the summer-autumn period, ascarids ( $T$. canis) in winter, whereas whipworms ( $T$. vulpis) peaked in winter, spring and summer. Once again, these data demonstrate a high risk of parasite infestation in all seasons in this part of the Americas.

\section{Diagnostic and management approaches Diagnosis of parasitic diseases}

The diagnosis of parasitic diseases affecting dogs and cats in Brazil is still predominately made by traditional methods. For instance, gastrointestinal parasites are usually detected by ordinary coprological techniques, such as Willis (flotation in saturated sodium chloride solution), Faust (zinc sulphate centrifugal flotation) and Hoffman-Pons-Janer (spontaneous faecal sedimentation in water) techniques $[188,189]$. These methods may present low sensitivity in some instances and result in the underestimation of the real prevalence of some parasites, such as D. caninum [74,77,100,188,190], when compared with necropsy data e.g., [32]. A commercial assay for faecal concentration (namely, TF-test ${ }^{\circledR}$ ) designed for detecting human intestinal parasites [191] has also been used for detecting helminth eggs, protozoan cysts and oocysts in canine faeces [190]. A comparative study revealed that the centrifugal flotation technique was more sensitive than centrifugal sedimentation and TF-test ${ }^{\oplus}$ in detecting Ancylostoma spp., T. canis, T. vulpis and Giardia in dog faeces [190]. Another study reported that the Willis technique was more efficient in detecting eggs of A. caninum and T. canis in dog faeces [188]. As a corollary, a more recent study showed that the Willis and the centrifugal flotation techniques performed better than the Hoffman-Pons-Janer technique for detecting Ancylostoma spp. in dog faeces [189]. Other methods have also been proposed, but apparently with no significant difference in terms of sensitivity, as compared with traditional methods [98]. The use of an enzyme linked immunosorbent assay (ELISA) for the detection E. granulosus coproantigen revealed high positivity rates (from 27.69 to $47.37 \%$ ) in rural dogs from southern Brazil [192]. In the same way, PCR-based techniques have been used to detect endoparasites (heminths and protozoa) of dogs in Brazil e. g., $[83,126,193,194]$ but currently these methods are mostly restricted to research.

Blood-dwelling protozoan parasites (e.g., B. vogeli and $H$. canis) are usually diagnosed by examination of stainedblood smears under a light microscope, which may lack in sensitivity, particularly if blood samples are collected outside the acute phase of the infection [195]. Serological tests are widely used to assess exposure to pathogens, such as B. vogeli, Leishmania spp., N. caninum, and T. gondii
[168,169,184,196-198]. The use of molecular tools for diagnosing protozoan parasites (e.g., B. vogeli, H. canis, and L. infantum) is becoming more and more popular, but it is still mostly restricted to research [121,199-204]. Indeed, current PCR protocols have shown a good level of concordance with parasitological methods [150]. Unfortunately, the costs of molecular tools are still prohibitive for most pet owners living in endemic areas and this severely impairs the diagnosis of diseases such as visceral and cutaneous leishmaniosis in dogs. Indeed, current serological tools cannot distinguish between L. braziliensis and L. infantum [113,205]. This may have direct implications for veterinary practitioners in Brazil because seropositive dogs are usually eliminated as part of the control programme against human visceral leishmaniosis, whilst it has been demonstrated that many of these dogs are infected by L. braziliensis rather than L. infantum $[113,205,206]$. Indeed, the high diversity of parasites in Brazil may be a confounding factor for the diagnosis of some diseases in dogs and cats in this country. For instance, different Leishmania species have been reported in these animals in Brazil and the clinical picture is not always predictable. A recent report described a case of canine leishmaniosis by L. infantum in which the dog presented a skin ulcer that is typically found in dogs and humans infected by L. braziliensis [207]. Again, dogs infected by L. amazonensis generally display clinical signs commonly observed in dogs with visceral leishmaniosis $[96,117]$. On the other hand, cats infected by $L$. amazonensis typically display a cutaneous disease that resembles sporotrichosis [141,208]. It means that the same parasite may eventually induce different clinical diseases in dogs and cats, which emphasizes the need for a proper laboratory diagnosis to confirm the parasite species involved. This is also true for eggs of ascarids (Toxocara spp.), and taenids (Taenia spp. and Echinococcus spp.) found in dog faeces, which cannot be normally differentiated by light microscopy [209,210]. Hookworm eggs are not easily distinguishable by morphology, but morphometric data suggests that they can be differentiated [211]. Nonetheless, the use of improved, specific diagnostic techniques is fundamental towards a better management of parasitic diseases of dogs and cats in Brazil.

\section{Controlling dog and cat parasites}

Veterinary practitioners working in Brazil are provided with a relatively vast repertory of tools to control parasites affecting dogs and cats. Nonetheless, the control of common parasites such as fleas and ticks may sometimes appear quite difficult, mainly when the available tools are not properly used or when veterinary practitioners do not possess basic knowledge on the bio-ecology of some of these parasites. In Brazil, there are no official guidelines 
for the control of ecto- and endoparasites of dogs and cats, such as those provided by European Scientific Counsel Companion Animal Parasites (ESCCAP: http:// www.esccap.org/) in Europe and the Companion Animal Parasite Council (CAPC: http://www.capcvet.org/) in the United States. These guidelines are fundamental to ensure the delivery of the latest scientific information on parasite control to veterinary practitioners.

Because lice and mites live in permanent association with their hosts, they are relatively easily controlled and, once eliminated, re-infestation only occurs following contact with other infested animals [212,213]. As such, the control of louse infestations in dogs and cats is mostly based on the application of insecticides on infested animals, which may be available as collars, spot-on solutions, and sprays [214-216]. Mites are also permanent ectoparasites, with some of them living in the fur (L. radovskyi), others in the outer ear canal (O. cynotis), hair follicles and sebaceous glands (D. canis and D. cati), or even in galleries burrowed under the epidermis ( $N$. cati e and $S$. scabiei). The treatment may be systemic (e.g., oral selamectin for S. scabiei) or topic (e.g., amitraz dip for D. canis). For instance, the treatment of infestations by the cat fur mite (L. radovskyi) in Brazil has been successfully performed with weekly baths using a soap containing tetramethylthiuram monosulfide [217]. Similarly, a single subcutaneous injection of doramectin $1 \%(0.3 \mathrm{mg} / \mathrm{kg})$ has been effective in treating dogs with sarcoptic mange and endoparasites as well [218]. However, the treatment of demodicosis in dogs may vary depending on case severity, animal age, and the presence of underlying conditions [219]. Indeed, most young dogs with juvenile-onset localized demodicosis will resolve spontaneously without treatment, whereas adult dogs with generalized demodicosis usually require aggressive therapy, for example, with amitraz dip every two weeks for several months [219]. Furthermore, an underlying disease or condition (e.g., cancer, hyperadrenocorticism, use of immunosuppressive drugs) should always be investigated and treated accordingly, especially in cases of demodicosis in adult dogs. It is clear that the treatment of mange in dogs and cats depends on several factors linked to the mite species involved and to the characteristics of each individual patient. Veterinary practitioners should use the products specifically labelled for mange treatment in dogs and cats in Brazil and strictly follow the manufacturer's recommendations.

In contrast to mites and lice, ticks and fleas are nonpermanent parasites [212] and therefore specimens found on dogs and cats may represent only a small proportion of the whole flea and tick population present in the environment where infested animals live. A vast repertory of products are available in the veterinary market in Brazil for controlling fleas and ticks on dogs and cats.
Insecticides and acaricides with potent anti-feeding and fast killing effects, repellents, insect growth regulators, and juvenile hormone analogues are available as spot-on pipettes, collars, shampoos, and sprays [212,220]. However, before deciding the best control strategy to be adopted, the veterinary practitioner should also investigate the presence and the abundance of fleas/ticks in the environment where the animal lives. Ticks tend to drop off during the night when the dog is sleeping [221]. Moreover, flea eggs are not sticky, falling from the animal's fur in the environment along with adult flea faeces. Newly hatched larvae usually avoid sunlight and actively move deep into carpet fibres or under organic debris [222]. Vacuuming places frequented by pets (e.g., carpets, furniture cushions, rugs, or other substrata), with a vacuum cleaner as well as washing of pet bedding or bed linen frequented by pets will help in the removal of flea eggs and larvae [222]. Furthermore, the treatment of the indoor and outdoor environment with insecticides and acaricides may be required in some situations, such as in kennels and catteries with high levels of environment flea and tick infestation. Care should be taken when applying chemical products in the environment and it is advisable that pet owners consult with a veterinarian or licensed pest control specialist [222].

The chemical control of other arthropods (e.g., kissing bugs, mosquitoes, and phlebotomine sand flies) in the environment is more complex and should also be performed in conjunction with public health authorities. For example, because mosquito larvae and pupae are strictly associated with water collections (e.g., containers, deactivated swimming pools, abandoned tyres), their population may be reduced and sometimes eradicated locally by destroying their breeding sites or by using biological control agents, such as the Bacillus thuringiensis israelensis and fishes such as bettas (Betta splendens) and guppies (Poecilia reticulata) [223,224]. The spraying of houses and animal shelters (e.g., chicken pen) with residual insecticides has long been recommended for controlling insect vectors, such as phlebotomine sand flies in Brazil [225,226]. However, results indicate that an effective vector population control may be difficult to achieve and resistance to insecticides currently in use in Brazil has been documented $[227,228]$. The use of insecticide-treated bed nets has also been proven to be effective in protecting humans against L. longipalpis bites [229], but this strategy is not currently used in Brazil as part of the national programme against zoonotic visceral leishmaniosis.

The control of common endoparasites of dogs (e.g., $A$. caninum and T. canis) and cats (e.g., A. braziliense and $T$. cati) usually consists of the routine administration of anthelminthics associated with vector control for those that are vector borne (e.g., D. caninum, D. immitis, and P. praeputialis); reviewed in Ref. [8]. Indeed, the control of zoonotic tapeworms (e.g., E. granulosus) may be 
effectively performed by the systematic use of praziquantel. For instance, a pilot control programme was conducted in southern Brazil, in which 44 rural dogs were treated monthly with praziquantel during 8 months [192]. At the beginning of the programme, 17 out 44 (28\%) dogs were positive for E. granulosus coproantigens by ELISA and 30 days after the last treatment administration no dog was found positive [192]. Specifically, in the case of the double-pore tapeworm $D$. caninum, the control of fleas and lice is also advocated [8].

The level of awareness and compliance of pet owners may be low in some settings, particularly in outskirts and rural areas. Even if an important part of pet owners in Brazil cannot handle the costs of year-round preventive programmes, the lack of compliance of wealthy people to cope with veterinary recommendations is usually due to their reduced risk perception. Alternative strategies have been proposed, including the use of the nematophagous fungus Pochonia chlamydosporia as a biological control agent against embryonated eggs of $T$. canis [230]. Nevertheless, these alternatives are still a bit far from reality in Brazil.

Finally, the control of vector-borne parasites is usually based on the use of repellents on animals and on the control of arthropod vectors in the environment, whenever applicable [9,231]; e.g., for the control of $H$. canis, which is associated with high levels of environmental tick infestation [232,233]. However, other strategies such as dog culling have long been used in Brazil to control zoonotic visceral leishmaniasis, even if this strategy has been considered unethical and scientifically unsound [234]. Recently, the Minister Joaquim Barbosa, President of the Supreme Federal Court of Brazil, refused the request to suspend the judgment of the Interministerial Ordinance 1.426/2008, which prohibits the treatment and recommends the euthanasia of $L$. infantum-infected dogs (www.brasileish.com.br/dados/artigos/artigos38155712122013. pdf). The Minister stated that this Ordinance violates the Federal Constitution and that the public power should find alternatives to confront this issue, in partnership with scientists and veterinarians.

\section{Prevention is better than cure}

Most dog owners seek the aid of a veterinary practitioner only when their animals display overt disease signs. This is particularly true in developing countries, where most dog owners cannot handle the costs of year-round preventive programmes. Naturally, in some rural and suburban areas the level of compliance may be even more reduced. Nonetheless, a considerable number of pet owners are increasingly aware of the risks and potential costs attached to the non-adoption of preventive measures directed at avoiding the exposure to certain pathogens, such as L. infantum. Thus, it is fundamental that veterinary practitioners recommend preventatives to pet owners towards the establishment of a long-term preventive programme against endoparasites and ectoparasites in Brazil.

The only vaccines against parasitic diseases available in Brazil are those against leishmaniosis, which are designed and approved against "canine leishmaniosis", not against "L. infantum infection". Indeed, none of the currently available vaccines against canine leishmaniosis will prevent dogs from becoming infected by L. infantum, but they should reduce the probability of vaccinated dogs to develop overt disease [231]. Importantly, if a vaccinated dog is able to mount an effective immune response against $L$. infantum, it will probably maintain the parasitic burden at low levels, eventually representing a poor source of parasites to phlebotomine vectors [235]. But again, it is important to emphasize that vaccines are not repellents and thus will not prevent dogs from being bitten by phlebotomine sand flies [235].

The use of repellents on dogs is an important strategy against ectoparasites and the pathogens they transmit [236-238]. Currently, there are several products formulated as spot-on solutions, collars, and sprays with fast killing effects, but synthetic pyrethroids remain the only chemical compounds with repellent properties available in the global veterinary market [239]. By virtue of their repellent and anti-feeding effects, synthetic pyrethroids (e.g., deltamethrin and permethrin) are highly efficacious against ectoparasites such as fleas, lice, sand flies, and ticks, but may also help to prevent the transmission of pathogens such as B. vogeli, E. canis, and L. infantum [236-238]. In the same way, some products with a fast killing effect are able to interrupt the attachment and blood feeding processes at their very early stages, thus also reducing the risk of pathogen transmission [240,241].

\section{Dogs, cats, parasites and humans: public health aspects}

While some dog and cat ectoparasites are strictly associated to these animals, some of them may also infest humans. For instance, cases of human infestation by dog-associated ticks (e.g., A. aureolatum, A. ovale, and $R$. sanguineus s.l.) have sporadically been described in different Brazilian regions [242-247]. Cases of human infestations by dog ticks ( $R$. sanguineus s.l.) appear to be associated with high levels of environmental infestation in human dwellings and with people working in veterinary clinics or kennels [242,244]. Importantly, some of these ticks may potentially transmit life-threatening pathogens to humans, including Rickettsia rickettsii [248]. For instance, $R$. sanguineus s.l. ticks have been implicated in the transmission of rickettsial organisms (e.g., Rickettsia conorii, Rickettsia massiliae, and $R$. rickettsii) to humans in the Mexico, the United States and the Mediterranean region [3]. Moreover, cases of human ehrlichiosis by $E$. canis have been described in Venezuela [249] and there is serological evidence that 
humans may be in jeopardy of being infected by $E$. canis in Brazil as well [250]. Importantly, E. canis is widespread and highly prevalent in Brazil [199,251-255], being primarily vectored by $R$. sanguineus s.l. ticks [256]. Cases of human infestation by Ctenocephalides spp. fleas have also been reported in Brazil [13,257], and it is now acknowledged that those fleas may carry Rickettsia felis [258], an emerging human pathogen worldwide [259]. It means that the control of some common dog and cat ectoparasites (e.g., C. felis felis and R. sanguineus s.l.) is fundamental not only for their health, but also to safeguard the health of their owners.

Ascarids (Toxocara spp.) and hookworms (Ancylostoma spp.) of dogs and cats are parasites of great veterinary and public health relevance, even if the general perception of pet owners is that intestinal parasites of dogs and cats are of minor public health significance; reviewed in Ref. [260]. For instance, a study carried out in southeastern Brazil revealed that most dog owners do not know the species of dog intestinal parasites, the mechanisms of transmission, the risk factors for zoonotic infections, and specific prophylactic measures [100]. Nonetheless, a number of cases of visceral and cutaneous larva migrans in humans have been described in Brazil [261-264] and serological data confirmed a high level of exposure to Toxocara spp. in humans in this country, reaching over 50\% in some cities [265-269]. Accordingly, high levels of environmental contamination by Toxocara and Ancylostoma eggs in public parks and squares have been reported in different Brazilian regions [270-274]. Furthermore, human lagochilascariasis is an emerging zoonosis in the Americas caused by the roundworm Lagochilascaris minor and has been sporadically reported in Brazil [275-279], which holds the largest number of human cases reported in the literature [280]. Cats have been found naturally infested by L. minor and Lagochilascaris major in Brazil [281-283]. Indeed, the role of cats as reservoirs of $L$. minor has been speculated [284] and the contamination by Lagochilascaris eggs in public playgrounds has been documented in southern Brazil [285]. The soil contamination by dog and cat faeces is a common phenomenon in public gardens, sand boxes, and beaches (Figure 5) in Brazil, not only due to the large population of stray animals present in the cities, but also due to the lack of proper sanitary and health education of some pet owners.

Tapeworms are also an underestimated problem in Brazil and other South American countries. For instance, human cases of $D$. caninum have been described in Brazil [286-288]. Indeed, the high prevalence of D. caninum in dogs in Brazil (e.g., 45.7\% in north-eastern and 36.8\% in south-eastern Brazil) [32,36] is a consequence of the high prevalence of flea and lice infestations reported in different regions of the country $[18,28,30,32,35]$ and indicates a

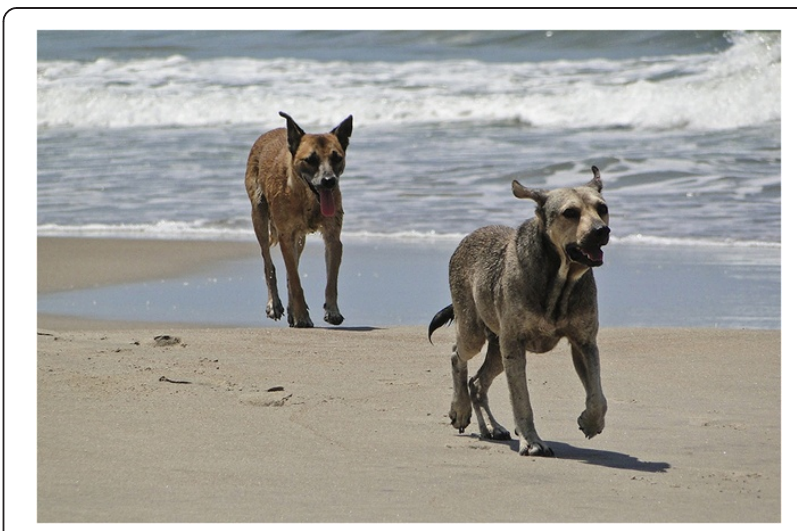

Figure 5 Environmental contamination with dog faeces. Stray dogs roaming freely in a beach in southern Brazil. Dog faeces are an important source of zoonotic parasites that may cause diseases such as cutaneous larva migrans.

high risk of zoonotic transmission in humans, particularly children, who live in close contact with infected animals. In the same way, cystic echinococcosis caused by E. granulosus is one of the most prevalent zoonosis in Argentina, Brazil, Chile, Peru, and Uruguay [289], being highly prevalent in southern Brazil, where up to $50 \%$ of the dogs may be infested [72,290]. While other canids (Pseudalopex gymnocercus, Cerdocyon thous, and Chrysocyon brachyurus) have been found naturally infested by E. granulosus in southern Brazil [290], dogs are the main reservoir of the parasite. In southern Brazil, E. granulosus is maintained principally in a dog-sheep cycle, with the sheep strain (G1) as the most prevalent genotype; reviewed in Ref. [290]. Furthermore, human cases of polycystic echinococcosis by Echinococcus vogeli have been diagnosed in northern Brazil [291] and dogs have also been suspected to play a role in the zoonotic transmission of this parasite in the Neotropical region [292]. Similarly, experimental evidence indicates that cats may act as definitive hosts for E. oligarthrus [293], another agent of polycystic echinococcosis in humans in Latin America [292], which is traditionally associated with wild felids. Last but not least, there is limited published information on other dog-associated taenids (e.g., T. hydatigena and T. multiceps) in Brazil [91], which suggests that human cysticercosis and coenuruses may be a silent, underestimated public health problem in some regions of this country.

Human pulmonary dirofilariosis is another common, yet underestimated public health issue in Brazil; reviewed in Ref. [294]. Even if several human cases have been described in the literature, most cases are accidentally found by chance on chest radiographies and chest computerized tomography scans, which are usually requested for other reasons [295]. Furthermore, even if most patients with 
pulmonary dirofilariosis present no apparent clinical signs, many of them will present cough, chest pain, haemoptysis, and dyspnoea [295-298]. Most importantly, the presence of pulmonary nodules could lead to the suspicion of diseases such as tuberculosis or lung cancer and in these cases thoracotomy is usually recommended. Indeed, human pulmonary dirofilariosis is a public health issue that has been so far neglected in Brazil. In the same way, the recent report of a case of ocular dirofilariosis in northern Brazil [299] suggests the risk of Dirofilaria infestation in certain Brazilian regions may be higher than currently appreciated.

Zoonotic protozoa are also a serious public health issue in Brazil. For instance, thousands of human cases of visceral leishmaniosis caused by L. infantum are notified each year to the Ministry of Health, but control measures mostly based on the elimination of seropositive dogs, vector control (in specific situations) and human treatment have not been enough to control the disease [300]. Indeed, human visceral leishmaniosis is widespread in all Brazilian regions, being less common in the southern part of the country [301]. The occurrence of asymptomatic Leishmania infections in humans has been documented in different regions of the country [302-304] and even if the Ministry of Health of Brazil affords the treatment of human patients, the lethality rate may reach $18.4 \%$ or much higher in some settings [305-307]. Another important zoonotic protozoan is T. gondii, an opportunistic pathogen highly prevalent in Brazil. Indeed, studies indicate that up to $50 \%$ of elementary school children and $50-80 \%$ of women of child-bearing age have anti- $T$. gondii antibodies; reviewed in Ref. [308]. A recent outbreak of acute toxoplasmosis in an industrial plant in São Paulo, south-eastern Brazil, indicated that ingestion of green vegetables (not meat or water) was associated with the incidence of acute disease [309]. Another recent study revealed a high seropositivity (80\%) among HIV-positive patients from southern Brazil, some of which had a history of neurotoxoplasmosis (4.8\%) and ocular toxoplasmosis (1.6\%) [310].

Chagas disease caused by $T$. cruzi remains an important public health issue in the Americas, affecting about $10 \%$ of the poorest people in the region [311]. Dogs and cats are considered important reservoirs of T. cruzi in the domestic cycle of transmission [312]. For instance, studies indicate that around $15-50 \%$ of dogs living in areas where Chagas disease is endemic are seropositive [313-318]. However, the real role played by dogs and cats in the transmission cycle of $T$. cruzi in the current epidemiological context of Chagas disease in Brazil is arguable, because the great majority of recent human cases have been associated with oral transmission, via the ingestion of contaminated juices [319].

\section{Final considerations and future research directions}

Brazil holds a vast territory and one of the largest dog and cat populations on the Planet. The economic growth and the increasing level of human development recorded in Brazil are provoking profound changes in the attitude of some dog owners and veterinary practitioners towards high-standard healthcare services. Nonetheless, the macroeconomic boom masks historical inequalities in terms of access to basic sanitation, decent housing, safe drinking water, health care and education at both local and regional levels. So, in reality, many dog owners cannot afford preventive measures and will act only when a life-threatening problem is affecting their animals. Furthermore, Brazil is still home to a large population of dogs and cats living as "strays" or "community" animals, not only in rural areas, but also in suburbs and large urban centres. Public health authorities are not able to manage these animals due to the lack of adequate infrastructure and trained personnel to conduct an effective long-term population control program. As a result, pet dogs and cats are usually endangered by a wide range of parasites that may cause disease in them and eventually in their human counterpart. This invariably brings us to the One Health concept, which invites veterinary practitioners and medical physicians to unify their efforts to combat zoonotic parasites (e.g., T. canis, A. caninum, D. caninum, D. immitis, E. granulosus, and L. infantum). Indeed, the unification of "veterinary and human medicines" in One Medicine is fundamental, instrumentally to reduce health hazards to pet animals and humans.

The outstanding diversity of ectoparasites infesting dogs and cats in Brazil is certainly a consequence of a combination of factors. The variety of natural environments and climates occurring in this country is impressive and favours the establishment of different parasites in all geographical regions. In the same way, dogs and cats living in either urban or rural areas may eventually live in close contact with livestock and wildlife species (e.g., foxes, wild cats, and opossums), which ultimately may favour the exchange of ectoparasites such as fleas and ticks with these animals [320-323]. For instance, $R$. sanguineus s.l. has been found on coati (Nasua nasua) living in a zoological park in a large urban area in north-eastern Brazil [322]. Even if this is an accidental finding, it suggests the presence of stray dogs circulating freely within the park's territory and living in close contact with captive wild animals. Conversely, dogs and cats intruding or living near to forested environments may be found infested by wildlife-associated ectoparasites $[12,28,50,321]$. The exchange of ectoparasites between domestic and wild animals may also have implications from a conservational perspective, also because dogs may exchange endoparasites [324-326] and viruses [327,328] with wildlife species. For example, several wild canids 
(e.g., C. thous and P. gymnocercus) and felids (e.g., Panthera onca, Puma concolor, Puma yagouaroundi, and Leopardus pardalis) have been found harbouring parasites that may affect dogs and cats, including heminths (e.g., A. caninum, D. caninum, T. canis, and T. vulpis) and protozoa (e.g., L. infantum) [324-326,329-333]. Remarkably, while freeroaming wild canids infected with $L$. infantum are usually asymptomatic, captive ones seems to be more prone to develop clinical signs [329] and may even die from infection [332].

Veterinary practitioners working in Brazil are provided with a vast repertory of products with proven efficacy against dog and cat parasites. Indeed, the registration of veterinary products in Brazil involves several phases and strict regulatory requirements [334]. However, the success of any parasite control programme depends on the correct use of the chosen product(s) and on the adoption of the best strategy for each situation. As previously discussed, guidelines for the diagnosis, treatment and control of dog and cat parasites in Brazil are currently lacking and are urgently needed. In the meantime, veterinary practitioners working in Brazil should adhere strictly to manufacturers' instructions while using commercially available products and follow international guidelines for the control of dog and cat parasites, eventually adapting them to regional situations. In addition, the Brazilian Ministry of Agriculture, Livestock and Food Supply recently established the use of a passport for international transit of dogs and cats (http://www.estadao.com.br/noticias/geral,caes-e-gatosterao-passaporte-e-identificacao-eletronica,1099476,0.htm). This passport will be used as a health certification of origin and will include information about ecto- and endoparasite control. This will help to reduce the risk of unintentional exportation of parasites from Brazil to overseas.

There are many outstanding questions regarding parasites of dogs and cats in Brazil, some of which may have already been answered at the time that this manuscript is being drafted. For instance, it is important to understand why some parasites are apparently restricted to the southern and south-eastern regions of Brazil [9]. This is the case of $R$. vitalii and B. gibsoni, for example. While B. gibsoni is a relatively rare parasite in dogs in Brazil, $R$. vitalii is quite common in southern and southeastern states and may cause severe disease that can be easily misdiagnosed with babesiosis or ehrlichiosis. Interestingly, the vectors of both protozoa remain unknown, but Amblyomma aureolatum is the putative vector for $R$. vitalii, at least. With this regard, the role of $R$. sanguineus s.l. in the natural cycle of $H$. canis in Brazil needs further investigation. Accordingly, other tick species have been implicated as putative vectors of this orally transmitted protozoan, including A. ovale [335,336] and Rhipicephalus microplus [337]. Some parasites of dogs and cats have only rarely been reported in Brazil, probably due to the limited research effort on these little studied parasites, whose veterinary and medical significance has yet to be ascertained. For instance, enigmatic parasites such as Cercopithifilaria bainae [338] have been originally described in Brazil, but remained doubtful and neglected for long time. Recently, this nematode was redescribed and it is emerging as a common filarioid of dogs in different European countries [339,340]. Altogether, these examples evidence that much has still to be discovered in Brazil regarding parasites of dogs and cats.

Further research on dog and cat parasites in Brazil may also reveal the existence of new species that have been overlooked over the years. Indeed, the use of molecular biology is revolutionizing in a positive fashion our knowledge on some "well-known" parasites, such as the brown dog tick $R$. sanguineus s.l. [52,161,162,341]. Likewise, genetic data suggested that nematodes identified as A. vasorum in dogs from South America may represent a different species from that observed in European dogs [342]. In this perspective, the use of molecular biology techniques should become a reality in the daily routine of veterinary practitioners working in Brazil and therefore the development of rapid, economically accessible molecular tools should be a research priority. For example, serological tests currently used by public authorities are not able to discriminate dogs infected by L. infantum from those infected by L. braziliensis or even distinguish vaccinated from naturally infected dogs [343]. Therefore, veterinary practitioners should request additional tests (e.g., parasite isolation and characterization, PCR and DNA sequencing) to confirm whether the dog is actually infected by $L$. infantum in order to avoid the elimination of dogs infected by other parasites and to decide about the most appropriate therapeutic approach to be adopted. With this respect, it is also important to monitor the emergence of resistance to certain active principles (e.g., amitraz, fipronil, deltamethrin, and permethrin), as these compounds have long been used for ectoparasite control in Brazil. Likewise, there is no information regarding the efficacy level of some endoparasiticides (e.g., praziquantel, pyrantel, febantel, and ivermectin), which are widely used in different Brazilian regions. These issues should be included in the research agenda of parasitologists in Brazil in order to anticipate problems related to parasite resistance to active principles currently used for controlling ectoparasites and endoparasites of dogs and cats in this country.

\section{Conclusions}

In conclusion, the benefits of having a dog or a cat as a pet are undisputed, but the limit between benefit and prejudice is subtle. Indeed, the close contact between pets and humans may involuntarily represent a hazard 
for humans. Therefore, to avoid the potential risks associated to owning a pet dog or cat, it is fundamental to maintain them in good health and protected from zoonotic pathogens. Beyond the shadow of a doubt, it is our job as veterinarians to ensure that pets and their owners may live in harmony without representing a menace to each other. But from a holistic perspective, veterinary practitioners and medical physicians should work together towards improving the wellbeing and general health of both animals and humans. Paraphrasing a famous American singer, a One Health approach could help us to "heal the world" and "make it a better place" for dogs, cats, and humans.

\section{Additional file}

Additional file 1: Portuguese version of this review article.

\section{Competing interests}

The authors declare that they have no competing interests.

\section{Authors' contributions}

FD-T wrote the manuscript and DO reviewed it critically. Both authors approved the final version of the manuscript.

\section{Acknowledgements}

Novartis Animal Health supported the preparation of this review. Thanks to Vinícius Roratto (Figure 1), Thiago André S. de Andrade (Figure 2), Fernando Silva and Pietra Lemos Costa (Figure 4), and Carlos A. P. Parchen (Figure 5) for sharing their photos. Thanks also to Viviana D. Tarallo for preparing the line drawings used in Figure 3, which were adapted from textbooks (e.g., Ref. [13]) and from photos kindly provided by Prof. Marcelo de Campos Pereira (http://www.icb.usp.br/ marcelcp/Default.htm).

Received: 13 November 2013 Accepted: 21 December 2013 Published: 14 January 2014

\section{References}

1. McConnell AR, Brown CM, Shoda TM, Stayton LE, Martin CE: Friends with benefits: on the positive consequences of pet ownership. J Pers Soc Psychol 2011, 101:1239-1252.

2. Irwin PJ: Companion animal parasitology: a clinical perspective. Int $J$ Parasitol 2002, 32:581-593.

3. Dantas-Torres F, Chomel BB, Otranto D: Ticks and tick-borne diseases: a One Health perspective. Trends Parasitol 2012, 28:437-446.

4. Lorusso V, Dantas-Torres F, Caprio F, Manzionna M, Santoro N, Baneth G Otranto D: Paediatric visceral leishmaniasis in Italy: a 'One Health' approach is needed. Parasit Vectors 2013, 6:123.

5. Pullan R, Brooker S: The health impact of polyparasitism in humans: are we under-estimating the burden of parasitic diseases? Parasitology 2008 135:783-794.

6. den Boer M, Argaw D, Jannin J, Alvar J: Leishmaniasis impact and treatment access. Clin Microbiol Infect 2011, 17:1471-1477.

7. Lustigman S, Prichard RK, Gazzinelli A, Grant WN, Boatin BA, McCarthy JS, Basáñez MG: A research agenda for helminth diseases of humans: the problem of helminthiases. PLoS Negl Trop Dis 2012, 6:e1582.

8. Ribeiro VM: Controle de helmintos de cães e gatos. Rev Bras Parasitol Vet 2004, 13(Suppl 1):88-95.

9. Dantas-Torres F: Canine vector-borne diseases in Brazil. Parasit Vectors 2008, 1:25.

10. Reck J, Soares JF, Termignoni C, Labruna MB, Martins JR: Tick toxicosis in a dog bitten by Ornithodoros brasiliensis. Vet Clin Pathol 2011, 40:356-360.

11. Evans DE, Martins JR, Guglielmone AA: A review of the ticks (Acari, ixodida) of Brazil, their hosts and geographic distribution - 1. The state of Rio Grande do Sul, southern Brazil. Mem Inst Oswaldo Cruz 2000, 95:453-470.
12. Labruna MB, Homem VS, Heinemann MB, Ferreira Neto JS: Ticks (Acari: Ixodidae) associated with rural dogs in Uruará, eastern Amazon, Brazil. J Med Entomol 2000, 37:774-776.

13. Linardi PM, Guimarães LR: Sifonápteros do Brasil. São Paulo: Museu de Zoologia USP/FAPESP; 2000.

14. Guimarães JH, Tucci EC, Barros-Battesti DM: Ectoparasitos de importância veterinária. São Paulo: Plêiade/FAPESP; 2001.

15. Rodrigues AFSF, Daemon E, D'Agosto M: Investigação sobre alguns ectoparasitos em cães de rua no município de Juiz de Fora, Minas Gerais. Rev Bras Parasitol Vet 2001, 10:13-19.

16. Szabó MP, Cunha TM, Pinter A, Vicentini F: Ticks (Acari: Ixodidae) associated with domestic dogs in Franca region, São Paulo, Brazil. Exp Appl Acarol 2001, 25:909-916.

17. Bellato V, Sartor AA, Souza AP, Ramos BC: Ectoparasites in dogs from Lages municipality, Santa Catarina, Brazil. Rev Bras Parasitol Vet 2003, 12:95-98.

18. Dantas-Torres F, Figueredo LA, Faustino MAG: Ectoparasites of dogs from some municipalities of the metropolitan region of Recife, Pernambuco state, Brazil. Rev Bras Parasitol Vet 2004, 13:151-154.

19. Heukelbach J, Costa AM, Wilcke T, Mencke N, Feldmeier H: The animal reservoir of Tunga penetrans in severely affected communities of north-east Brazil. Med Vet Entomol 2004, 18:329-335.

20. Souza CP, Scott FB, Pereira MJS: Validity and reprodutibility of otoscopy and pinnal pedal reflex on the diagnostic of Otodectes cynotis infestation in dogs. Rev Bras Parasitol Vet 2004, 13:111-114.

21. Scofield A, Riera MDF, Elisei C, Massard CL, Linardi PM: Occurrence of Rhopalopsyllus lutzi lutzi (Baker) (Siphonaptera, Rhopalopsyllidae) on Canis familiaris (Linnaeus) from rural areas of the county of Piraí, State of Rio de Janeiro, Brazil. Rev Bras Entomol 2005, 49:159-161.

22. Castro MCM, Rafael JA: Ectoparasites on cats and dogs from Manaus, Amazonas State, Brazil. Acta Amaz 2006, 36:535-538.

23. Soares AO, Souza AD, Feliciano EA, Rodrigues AF, D'Agosto M, Daemon E: Evaluation of ectoparasites and hemoparasites in dogs kept in apartments and houses with yards in the city of Juiz de Fora, Minas Gerais, Brazil. Rev Bras Parasitol Vet 2006, 15:13-16.

24. Dantas-Torres F, Figueredo LA: Heterodoxus spiniger (Enderlein, 1909) on domestic dogs (Canis familiaris, L. 1758) from the city of Recife, Pernambuco state, Brazil. Braz I Vet Res Anim Sci 2007, 43:77-80.

25. Szabó MP, Olegário MM, Santos AL: Tick fauna from two locations in the Brazilian savannah. Exp Appl Acarol 2007, 43:73-84.

26. Cardoso CP, Stalliviere FM, Schelbauer CA, de Souza AP, Bellato V, Sartor AA: Amblyomma tigrinum in the municipality of Lages, SC, and biology observations under laboratory conditions. Rev Bras Parasitol Vet 2008, 17:56-58.

27. Rocha GS, Ahid SMM, Bezerra ACDS, Filgueira KD, Santos JPS: Mites frequency in dogs and cats at the city of Mossoro, Rio Grande do Norte, Brazil. Acta Sci Vet 2008, 36:263-266.

28. Rodrigues DF, Daemon E, Rodrigues AF: Characterization of ectoparasites on dogs in the nucleus of urban expansion of Juiz de Fora, Minas Gerais, Brazil. Rev Bras Parasitol Vet 2008, 17:185-188.

29. Dantas-Torres F: Ticks on domestic animals in Pernambuco, Northeastern Brazil. Rev Bras Parasitol Vet 2009, 18:22-28.

30. Dantas-Torres F, Melo MF, Figueredo LA, Brandão-Filho SP: Ectoparasite infestation on rural dogs in the municipality of São Vicente Férrer, Pernambuco, Northeastern Brazil. Rev Bras Parasitol Vet 2009, 18:75-77.

31. Martins TF, Spolidorio MG, Batista TC, Oliveira IA, Yoshinari NH, Labruna MB: Occurrence of ticks (Acari: Ixodidae) in the municipality of Goiatins, Tocantins. Rev Bras Parasitol Vet 2009, 18:50-52.

32. Klimpel S, Heukelbach J, Pothmann D, Rückert S: Gastrointestinal and ectoparasites from urban stray dogs in Fortaleza (Brazil): high infection risk for humans? Parasitol Res 2010, 107:713-719.

33. Szabó MP, de Souza LG, Olegário MM, Ferreira FA FA, de Albuquerque Pajuaba Neto A: Ticks (Acari: Ixodidae) on dogs from Uberlândia, Minas Gerais, Brazil. Transbound Emerg Dis 2010, 57:72-74.

34. Guimarães AM, Lima BS, Rocha CMBM: Parasitic ectofauna of urban domiciled dogs examined in private veterinary clinics from Lavras municipality, Minas Gerais state, Brazil. Cien Anim Bras 2011, 12:172-177.

35. Costa-Junior LM, Rembeck K, Mendonça FL, Azevedo SC, Passos LM, Ribeiro MF: Occurrence of ectoparasites on dogs in rural regions of the state of Minas Gerais, Brazil. Rev Bras Parasitol Vet 2012, 21:237-242.

36. Heukelbach J, Frank R, de Ariza L, de Sousa Lopes I, de Assis E, Silva A, Borges AC, Limongi JE, de Alencar CH, Klimpel S: High prevalence of 
intestinal infections and ectoparasites in dogs, Minas Gerais State (southeast Brazil). Parasitol Res 2012, 111:1913-1921.

37. Mazioli R, Szabó M, Mafra C: Amblyomma nodosum (Acari: Ixodidae) parasitizing a domestic dog in Colatina, Espírito Santo, Brazil. Rev Bras Parasitol Vet 2012, 21:428-432.

38. Santos JL, Magalhães NB, Dos Santos HA, Ribeiro RR, Guimarães MP: Parasites of domestic and wild canids in the region of Serra do Cipó National Park, Brazil. Rev Bras Parasitol Vet 2012, 21:270-277.

39. Costa AP, Silva AB, Costa FB, Xavier GS, Martins TF, Labruna MB, Guerra RM: A survey of ectoparasites infesting urban and rural dogs of Maranhão state, Brazil. J Med Entomol 2013, 50:674-678.

40. Reck J, Marks FS, Guimarães JA, Termignoni C, Martins JR: Epidemiology of Ornithodoros brasiliensis (mouro tick) in the southern Brazilian highlands and the description of human and animal retrospective cases of tick parasitism. Ticks Tick Borne Dis 2013, 4:101-109.

41. Souza CP, Verocai GG, Balbi M, Scott FB: Video otoscopy as a diagnostic tool for canine otoacariasis. Rev Bras Parasitol Vet 2013, 22:440-442.

42. Mendes-de-Almeida F, Faria MC, Branco AS, Serrão ML, Souza AM, Almosny $\mathrm{N}$, Charme M, Labarthe N: Sanitary conditions of a colony of urban feral cats (Felis catus Linnaeus, 1758) in a zoological garden of Rio de Janeiro, Brazil. Rev Inst Med Trop Sao Paulo 2004, 46:269-274.

43. Pereira SA, Schubach TMP, Figueiredo FB, Paes Leme LR, Santos IB, Okamoto T, Cuzzi T, Reis RS, Schubach A: Demodicosis associated with sporotrichosis and pediculosis in a positive FIV/FeLV cat. Acta Sci Vet 2005, 33:75-78.

44. Mendes-de-Almeida F, Labarthe N, Guerrero J, Faria MC, Branco AS, Pereira CD, Barreira JD, Pereira MJ: Follow-up of the health conditions of an urban colony of free-roaming cats (Felis catus Linnaeus, 1758) in the city of Rio de Janeiro, Brazil. Vet Parasitol 2007, 147:9-15.

45. Romeiro ET, Alves LC, Soares YM, Matoso UN, Faustino MA: Infestation by Lynxacarus radovskyi (Tenorio, 1974) in domestic cats from Metropolitan Region of Recife, Pernambuco, Brazil. Rev Bras Parasitol Vet 2007, 16:159-162

46. Aguiar J, Machado MLS, Ferreira RR, Hünning PS, Muschner AC, Ramos RZ: Mixed infestation by Lynxacarus radovskyi and Felicola subrostratus in a cat in Porto Alegre, RS, Brazil. Acta Scie Vet 2009, 37:301-305.

47. Stalliviere FM, Bellato V, Souza AP, Sartor AA, Moura AB, Rosa LD: Ectoparasites and intestinal helminths in Felis catus domesticus from Lages city, SC, Brazil and social-economical and cultural aspects of owners of family pets. Rev Bras Parasitol Vet 2009, 18:26-31.

48. Ferreira DRA, Alves LC, Faustino MAG: Ectoparasitic species from Felis catus domesticus (Linnaeus, 1758) in João Pessoa city, Paraíba state, Brazil. Biotemas 2010, 23:43-50.

49. Mendes-de-Almeida F, Crissiuma AL, Gershony LC, Willi LM, Paiva JP, Guerrero J, Labarthe N: Characterization of ectoparasites in an urban cat (Felis catus Linnaeus, 1758) population of Rio de Janeiro, Brazil. Parasito Res 2011, 108:1431-1435.

50. Silva AS, Silva MK, Monteiro SG: Parasitism by Amblyomma triste in domestic cat. Rev Bras Parasitol Vet 2007, 16:108-109.

51. Linardi PM, Santos JL: Ctenocephalides felis felis vs. Ctenocephalides canis (Siphonaptera: Pulicidae): some issues in correctly identify these species. Rev Bras Parasitol Vet 2012, 21:345-354.

52. Dantas-Torres F, Latrofa MS, Annoscia G, Giannelli A, Parisi A, Otranto D: Morphological and genetic diversity of Rhipicephalus sanguineus sensu lato from the New and Old Worlds. Parasit Vectors 2013, 6:213.

53. Barros-Battesti DM, Arzua M, Bechara GH: Carrapatos de importância médico-veterinária da Região Neotropical: Um guia ilustrado para identificação de espécies. São Paulo. Butantan: Vox/International Consortium on Ticks and Tick-borne Diseases (ICTTD-3); 2006

54. Aragão HB, Fonseca F: Notas de ixodologia. VIII. Lista e chave para os representantes da fauna ixodológica brasileira. Mem Inst Oswaldo Cruz 1961, 59:115-129.

55. Labruna MB, Campos Pereira M: Carrapato em cães no Brasil. Clin Vet 2001, 30:24-32.

56. Martins TF, Onofrio VC, Barros-Battesti DM, Labruna MB: Nymphs of the genus Amblyomma (Acari: Ixodidae) of Brazil: descriptions, redescriptions, and identification key. Ticks Tick Borne Dis 2010, 1:75-99.

57. Azeredo-Espin AM, Madeira NG: Primary myiasis in dog caused by Phaenicia eximia (Diptera: Calliphoridae) and preliminary mitochondrial DNA analysis of the species in Brazil. J Med Entomol 1996, 33:839-843.

58. Silva Junior VP, Souza Leandro A, Moya Borja GE: Occurrence of berne, Dermatobia hominis (Diptera: Cuterebridae) in several host, in the Rio de Janeiro. Brazil. Parasitol día 1998, 22:97-101.
59. Cramer-Ribeiro BC, Sanavria A, Oliveira MQ, Souza FS, Rocco FS, Cardoso PG: Inquiry of cases of myiasis by Cochliomyia hominivorax in dogs of the southern zone of Rio de Janeiro city in 2000. Braz J Vet Res Anim Sci 2002, 39:171-175.

60. Cramer-Ribeiro BC, Sanavria A, Oliveira MQ, Souza FS, Rocco FS, Cardoso PG: Inquiry of cases of myiasis by Dermatobia hominis in dogs of the southern zone of Rio de Janeiro municipality in 2000. Braz J Vet Res Anim Sci 2002, 39:176-180.

61. Cramer-Ribeiro BC, Sanavria A, Monteiro HHMS, Oliveira MQ, Souza FS: Inquiry of cases of myiasis by Cochliomyia hominivorax in dogs (Canis familiaris) of the Northern and Western zones of Rio de Janeiro city in 2000. Braz J Vet Res Anim Sci 2003, 40:13-20.

62. Cardozo SV, Ramadinha RR: Evaluation of myiasis treatment in dogs using nitenpyram. R Bras Ci Vet 2007, 14:139-142.

63. Correia TR, Scott FB, Verocai GG, Souza CP, Fernandes JI, Melo RM, Vieira VP, Ribeiro FA: Larvicidal efficacy of nitenpyram on the treatment of myiasis caused by Cochliomyia hominivorax (Diptera: Calliphoridae) in dogs. Vet Parasitol 2010, 173:169-172

64. Marotta CR, Scherer PO, Sanavria A: Cutaneous and oro-nasal internal myiasis by Cochliomyia hominivorax (Coquerel, 1858) in feline (Felis catus) - Case report. Rev Bras Med Vet 2011, 33:137-141.

65. Cansi ER, Demo C: Occurrence of myiasis in pets from the Federal District, in Brazil. Acta Sci Vet 2011, 39:982.

66. Barros ATM, Koller WW, Catto JB, Soares CO: Stomoxys calcitrans outbreaks in pastured beef cattle in the State of Mato Grosso do Sul, Brazil. Pesa Vet Bras 2010, 30:945-952.

67. Freitas MG, Costa HMA: Lista de helmintos parasitos dos animais domésticos do Brasil. Arq Esc Vet UFMG 1959, 12:443-510.

68. Travassos L, Freitas JFT, Kohn A: Trematódeos do Brasil. Mem Inst Oswaldo Cruz 1959, 67:1-886.

69. Vicente JJ, Rodrigues HO, Gomes DC, Pinto RM: Nematóides do Brasil. Parte V. Nematóides de mamíferos. Rev Bras Zool 1997, 14(Supl 1):1-452.

70. Costa JO, Guimarães MP, Lima WS, Lima EA: Endo and ectoparasites of dogs from Vitoria county - Espírito Santo - Brazil. Ara Bras Med Vet Zootec 1990, 42:451-452.

71. Gennari SM, Kasai N, Pena HFJ, Cortez A: Occurrence of protozoa and helminthes in faecal samples of dogs and cats from São Paulo city. Braz J Vet Res An Sci 1999, 36:87-91.

72. Hoffmann AN, Malgor R, de la Rue ML: Prevalence of Echinococcus granulosus (Batsch, 1786) in urban stray dogs from Dom Pedrito in the state of Rio Grande do Sul, Brazil. Cienc Rural 2001, 31:843-847.

73. Gontijo CM, da Silva ES, de Fuccio MB, de Sousa MC, Pacheco RS, Dias ES, Andrade Filho JD, Brazil RP, Melo MN: Epidemiological studies of an outbreak of cutaneous leishmaniasis in the Rio Jequitinhonha Valley, Minas Gerais, Brazil. Acta Trop 2002, 81:143-150.

74. Oliveira-Sequeira TC, Amarante AF, Ferrari TB, Nunes LC: Prevalence of intestinal parasites in dogs from São Paulo State, Brazil. Vet Parasitol 2002, 103:19-27.

75. Oliveira-Júnior SD, Barçante JM, Barçante TA, Ribeiro VM, Lima WS: Ectopic location of adult worms and first-stage larvae of Angiostrongylus vasorum in an infected dog. Vet Parasitol 2004, 121:293-296.

76. Sreekumar C, Hill DE, Miska KB, Rosenthal BM, Vianna MC, Venturini L, Basso W, Gennari SM, Lindsay DS, Dubey JP: Hammondia heydorni: evidence of genetic diversity among isolates from dogs. Exp Parasitol 2004, 107:65-71.

77. Blazius RD, Emerick S, Prophiro JS, Romão PR, Silva OS: Occurrence of protozoa and helminthes in faecal samples of stray dogs from Itapema City, Santa Catarina. Rev Soc Bras Med Trop 2005, 38:73-74.

78. Herrera HM, Norek A, Freitas TP, Rademaker V, Fernandes O, Jansen AM: Domestic and wild mammals infection by Trypanosoma evansi in a pristine area of the Brazilian Pantanal region. Parasitol Res 2005, 96:121-126

79. Passos LM, Geiger SM, Ribeiro MF, Pfister K, Zahler-Rinder M: First molecula detection of Babesia vogeli in dogs from Brazil. Vet Parasitol 2005, 127:81-85.

80. Rubini AS, dos Santos PK, Cavalcante GG, Ribolla PE, O'Dwyer LH: Molecular identification and characterization of canine Hepatozoon species from Brazil. Parasitol Res 2005, 97:91-93.

81. Savani ES, Nunes VL, Galati EA, Castilho TM, Araujo FS, Ilha IM, Camargo MC, D'Auria SR, Floeter-Winter LM: Occurrence of co-infection by Leishmania (Leishmania) chagasi and Trypanosoma (Trypanozoon) evansi in a dog in the state of Mato Grosso do Sul, Brazil. Mem Inst Oswaldo Cruz 2005, 100:739-741. 
82. Andrade HM, Reis $A B$, dos Santos SL, Volpini AC, Marques MJ, Romanha AJ: Use of PCR-RFLP to identify Leishmania species in naturally-infected dogs. Vet Parasitol 2006, 140:231-238

83. Silva LM, Miranda RR, Santos HA, Rabelo EM: Differential diagnosis of dog hookworms based on PCR-RFLP from the ITS region of their rDNA. Vet Parasitol 2006, 40:373-377.

84. Labruna MB, Pena HFJ, Souza SLP, Pinter A, Silva JCR, Ragozo AMA, Camargo LMA, Gennari SM: Prevalence of endoparasites in dogs from the urban area of Monte Negro municipality, Rondônia, Brazil. Arq Inst Biol São Paulo 2006, 73:183-193.

85. Madeira MF, Schubach A, Schubach TM, Pacheco RS, Oliveira FS, Pereira SA Figueiredo FB, Baptista C, Marzochi MC: Mixed infection with Leishmania (Viannia) braziliensis and Leishmania (Leishmania) chagasi in a naturally infected dog from Rio de Janeiro, Brazil. Trans R Soc Trop Med Hyg 2006, 100:442-445.

86. Pereira BJ, Girardelli GL, Trivilin LO, Lima VR, Nunes Lde C, Martins IV: The occurrence of dioctophymosis in dogs from Municipality of Cachoeiro do Itapemirim in the State of Espírito Santo, Brazil, from May to December of 2004. Rev Bras Parasitol Vet 2006, 15:123-125.

87. Trapp SM, Messick JB, Vidotto O, Jojima FS, de Morais HS: Babesia gibsoni genotype Asia in dogs from Brazil. Vet Parasitol 2006, 141:177-180.

88. Velasquez LG, Membrive N, Membrive U, Rodrigues G, Reis N, Lonardoni MV, Teodoro U, Tessmann IP, Silveira TG: PCR in the investigation of canine American tegumentary leishmaniasis in northwestern Paraná State, Brazil. Cad Saude Publica 2006, 22:571-578.

89. Forlano MD, Teixeira KR, Scofield A, Elisei C, Yotoko KS, Fernandes KR, Linhares GF, Ewing SA, Massard CL: Molecular characterization of Hepatozoon sp. from Brazilian dogs and its phylogenetic relationship with other Hepatozoon spp. Vet Parasitol 2007, 145:21-30.

90. Gomes AH, Ferreira IM, Lima ML, Cunha EA, Garcia AS, Araújo MF, PereiraChioccola VL: PCR identification of Leishmania in diagnosis and control of canine leishmaniasis. Vet Parasitol 2007, 144:234-241.

91. Katagiri S, Oliveira-Sequeira TCG: Zoonoses caused by dog intestinal parasites and the problem of diagnosis. Arq Inst Bio/ 2007, 74:175-184

92. Mundim MJ, Rosa LA, Hortêncio SM, Faria ES, Rodrigues RM, Cury MC: Prevalence of Giardia duodenalis and Cryptosporidium spp. in dogs from different living conditions in Uberlândia, Brazil. Vet Parasito/ 2007, 144:356-359.

93. Nakagawa TL, Bracarense AP, dos Reis AC, Yamamura MH, Headley SA: Giant kidney worm (Dioctophyma renale) infections in dogs from Northern Paraná, Brazil. Vet Parasitol 2007, 145:366-370.

94. Souza SL, Gennari SM, Richtzenhain LJ, Pena HF, Funada MR, Cortez A Gregori F, Soares RM: Molecular identification of Giardia duodenalis isolates from humans, dogs, cats and cattle from the state of São Paulo, Brazil, by sequence analysis of fragments of glutamate dehydrogenase (gdh) coding gene. Vet Parasitol 2007, 149:258-264.

95. Thomaz A, Meireles MV, Soares RM, Pena HF, Gennari SM: Molecular identification of Cryptosporidium spp. from fecal samples of felines, canines and bovines in the state of São Paulo, Brazil. Vet Parasitol 2007, 150:291-296.

96. Tolezano JE, Uliana SR, Taniguchi HH, Araújo MF, Barbosa JA, Barbosa JE, Floeter-Winter LM, Shaw JJ: The first records of Leishmania (Leishmania) amazonensis in dogs (Canis familiaris) diagnosed clinically as having canine visceral leishmaniasis from Araçatuba County, São Paulo State, Brazil. Vet Parasitol 2007, 149:280-284.

97. Volotão AC, Costa-Macedo LM, Haddad FS, Brandão A, Peralta JM, Fernandes $\mathrm{O}$ : Genotyping of Giardia duodenalis from human and animal samples from Brazil using beta-giardin gene: a phylogenetic analysis. Acta Trop 2007, 102:10-19.

98. Campos Filho PC, Barros LM, Campos JO, Braga VB, Cazorla IM, Albuquerque GR, Carvalho SM: Zoonotic parasites in dog feces at public squares in the municipality of Itabuna, Bahia, Brazil. Rev Bras Parasitol Vet 2008, 17:206-209.

99. Fernandes AB, Baêta BA, Filho WF, Massad FV, Rebouças FA, De Carvalho JB, Lopes CW: Relationship between companion animals and intestinal parasites in children at municipality of Seropédica, RJ. Rev Bras Parasitol Vet 2008, 17(Suppl 1):296-300.

100. Katagiri S, Oliveira-Sequeira TC: Prevalence of dog intestinal parasites and risk perception of zoonotic infection by dog owners in São Paulo State, Brazil. Zoonoses Public Health 2008, 55:406-413.

101. Meireles P, Montiani-Ferreira F, Thomaz-Soccol V: Survey of giardiosis in household and shelter dogs from metropolitan areas of Curitiba, Paraná state, Southern Brazil. Vet Parasitol 2008, 152:242-248.
102. Oliveira Lima AN, da Silva SS, Herrera HM, Gama C, Cupolillo E, Jansen AM, Fernandes O: Trypanosoma evansi: molecular homogeneity as inferred by phenetical analysis of ribosomal internal transcribed spacers DNA of an eclectic parasite. Exp Parasitol 2008, 118:402-407.

103. Rubini AS, dos Santos PK, Von Ah LV, O'Dwyer LH: Molecular and parasitological survey of Hepatozoon canis (Apicomplexa: Hepatozoidae) in dogs from rural area of São Paulo state, Brazil. Parasitol Res 2008, 102:895-899.

104. Shigueru FJ, Garcia JL, Vidotto MC, Balarin MR, Fabretti AK, Gasparini MR, Coelho AL, Vidotto O: Occurrence and molecular characterization of Babesia species in a canine hospital population in the Londrina Region, Paraná State, Brazil. Rev Bras Parasitol Vet 2008, 17(Suppl 1):277-283.

105. Torrico KJ, Santos KR, Martins T, Silva FM P e, Takahira RK, Lopes RS: Occurrence of gastrointestinal parasites in dogs and cats in the laboratory of routine of parasitic diseases FMVZ/Unesp-Botucatu, SP. Rev Bras Parasitol Vet 2008, 17(Suppl 1):182-183.

106. Costa-Júnior LM, Ribeiro MF, Rembeck K, Rabelo EM, Zahler-Rinder M, Hirzmann J, Pfister K, Passos LM: Canine babesiosis caused by Babesia canis vogeli in rural areas of the State of Minas Gerais, Brazil and factors associated with its seroprevalence. Res Vet Sci 2009, 86:257-260.

107. Furtado AP, Do Carmo ES, Giese EG, Vallinoto AC, Lanfredi RM, Santos JN: Detection of dog filariasis in Marajo Island, Brazil by classical and molecular methods. Parasitol Res 2009, 105:1509-1515.

108. Madeira MF, Sousa MA, Barros JH, Figueiredo FB, Fagundes A, Schubach A, DE Paula CC, Faissal BN, Fonseca TS, Thoma HK, Marzochi MC: Trypanosoma caninum n. sp. (Protozoa: Kinetoplastida) isolated from intact skin of a domestic dog (Canis familiaris) captured in Rio de Janeiro, Brazil. Parasitology 2009, 136:411-423.

109. O'Dwyer LH, Lopes W, Rubini AS, Paduan Kdos S, Ribolla PE: Babesia spp. infection in dogs from rural areas of São Paulo State, Brazil. Rev Bras Parasitol Vet 2009, 18:23-26.

110. Oliveira LP, Cardozo GP, Santos EV, Mansur MA, Donini IA, Zissou VG, Roberto PG, Marins M: Molecular analysis of the rRNA genes of Babesia spp and Ehrlichia canis detected in dogs from Ribeirão Preto, Brazil. Braz J Microbiol 2009, 40:238-240.

111. Quaresma PF, Murta SM, Ferreira Ede C, Rocha-Lima AC, Xavier AA, Gontijo CM: Molecular diagnosis of canine visceral leishmaniasis: identification of Leishmania species by PCR-RFLP and quantification of parasite DNA by real-time PCR. Acta Trop 2009, 111:289-294.

112. Spolidorio MG, Labruna MB, Zago AM, Donatele DM, Caliari KM, Yoshinari $\mathrm{NH}$ : Hepatozoon canis infecting dogs in the State of Espírito Santo, southeastern Brazil. Vet Parasitol 2009, 163:357-361.

113. Dantas-Torres F, de Paiva-Cavalcanti M, Figueredo LA, Melo MF, Silva FJ, Silva AL, Almeida EL, Brandão-Filho SP: Cutaneous and visceral leishmaniasis in dogs from a rural community in northeastern Brazil. Vet Parasitol 2010, 170:313-317

114. Gomes PV, Mundim MJ, Mundim AV, de Ávila DF, Guimarães EC, Cury MC: Occurrence of Hepatozoon sp. in dogs in the urban area originating from a municipality in southeastern Brazil. Vet Parasitol 2010, 174:155-161.

115. Sevá AP, Funada MR, Souza SO, Nava A, Richtzenhain LJ, Soares RM: Occurrence and molecular characterization of Cryptosporidium spp. isolated from domestic animals in a rural area surrounding Atlantic dry forest fragments in Teodoro Sampaio municipality, State of São Paulo, Brazil. Rev Bras Parasitol Vet 2010, 19:249-253.

116. Coelho WM, Amarante AF, Apolinário Jde C, Coelho NM, Bresciani KD: Occurrence of Ancylostoma in dogs, cats and public places from Andradina city, São Paulo state, Brazil. Rev Inst Med Trop Sao Paulo 2011, 53:181-184.

117. Dias ES, Regina-Silva S, França-Silva JC, Paz GF, Michalsky EM, Araújo SC, Valadão JL, de Oliveira Lara-Silva F, de Oliveira FS, Pacheco RS, Fortes-Dias $\mathrm{CL}$ : Eco-epidemiology of visceral leishmaniasis in the urban area of Paracatu, state of Minas Gerais, Brazil. Vet Parasitol 2011, 176:101-111.

118. Duarte SC, Parente JA, Pereira M, Soares CM, Linhares GF: Phylogenetic characterization of Babesia canis vogeli in dogs in the state of Goiás, Brazil. Rev Bras Parasitol Vet 2011, 20:274-280.

119. Soares JF, Girotto A, Brandão PE, Da Silva AS, França RT, Lopes ST, Labruna MB: Detection and molecular characterization of a canine piroplasm from Brazil. Vet Parasitol 2011, 180:203-208.

120. Costa LM Jr, Zahler-Rinder M, Ribeiro MF, Rembeck K, Rabelo EM, Pfister K Passos LM: Use of a Real Time PCR for detecting subspecies of Babesia canis. Vet Parasitol 2012, 188:160-163. 
121. Eloy $L$, Lucheis SB: Hemoculture and polymerase chain reaction using primers TCZ1/TCZ2 for the diagnosis of canine and feline trypanosomiasis. ISRN Vet Sci 2012, 2012:419378.

122. Gonçalves AQ, Ascaso C, Santos I, Serra PT, Julião GR, Orlandi PP: Calodium hepaticum: household clustering transmission and the finding of a source of human spurious infection in a community of the Amazon region. PLOS Negl Trop Dis 2012, 6:e1943.

123. Langoni H, Matteucci G, Medici B, Camossi LG, Richini-Pereira VB, Silva RC: Detection and molecular analysis of Toxoplasma gondii and Neospora caninum from dogs with neurological disorders. Rev Soc Bras Med Trop 2012, 45:365-368

124. Lemos TD, Cerqueira Ade M, Toma HK, Silva AV, Corrêa RG, Paludo GR, Massard CL, Almosny NR: Detection and molecular characterization of piroplasms species from naturally infected dogs in southeast Brazil. Rev Bras Parasitol Vet 2012, 21:137-142.

125. Martins CM, Barros CC, Bier D, Marinho AP, Figueiredo JM, Hoffmann JL, Molento MB, Biondo AW: Dog parasite incidence and risk factors, from sampling after one-year interval, in Pinhais, Brazil. Rev Bras Parasitol Vet 2012, 21:101-106.

126. Silva FM P e, Monobe MM, Lopes RS, Araujo JP Jr: Molecular characterization of Giardia duodenalis in dogs from Brazil. Parasitol Res 2012, 110:325-334

127. Santana VL, Souza AP, Lima DASD, Araújo AL, Justiniano SV, Dantas RP, Guedes PMM, Melo MA: Clinical and laboratorial characterization of naturally infected Trypanosoma cruzi dogs in the northeastern semi-arid. Pesq Vet Bras 2012, 32:536-541.

128. Leça Júnior NF, Dos Anjos Almeida V, Santos Carvalho F, Rego Albuquerque G, Lessa Silva F: First report of Trypanosoma cruzi infection in naturally infected dogs from southern Bahia, Brazil. Rev Bras Parasitol Vet. in press.

129. Morais RC, Gonçalves SC, Costa PL, da Silva KG, da Silva FJ, Silva RP, de Brito ME, Brandão-Filho SP, Dantas-Torres F, de Paiva-Cavalcanti M: Detection of Leishmania infantum in animals and their ectoparasites by conventional PCR and real time PCR. Exp Appl Acarol 2013, 59:473-481.

130. Rocha FL, Roque AL, Arrais RC, Santos JP, Lima VS, Xavier SC, Cordeir-Estrela P, D'Andrea PS, Jansen AM: Trypanosoma cruzi Tcl and Tcll transmission among wild carnivores, small mammals and dogs in a conservation unit and surrounding areas, Brazil. Parasitology 2013, 140:160-170.

131. Labarthe N, Ferreira AM, Guerrero J, Newcomb K, Paes-de-Almeida E: Survey of Dirofilaria immitis (Leidy, 1856) in random source cats in metropolitan Rio de Janeiro, Brazil, with descriptions of lesions. Vet Parasitol 1997 71:301-306.

132. Serra CM, Uchôa CM, Coimbra RA: Parasitological study with faecal samples of stray and domiciliated cats (Felis catus domesticus) from the Metropolitan Area of Rio de Janeiro, Brazil. Rev Soc Bras Med Trop 2003, 36:331-334.

133. Labarthe N, Serrão ML, Ferreira AM, Almeida NK, Guerrero J: A survey of gastrointestinal helminths in cats of the metropolitan region of Rio de Janeiro, Brazil. Vet Parasitol 2004, 123:133-139.

134. Coelho WM, do Amarante AF, de Soutello RV, Meireles MV Bresciani KD: Occurrence of gastrointestinal parasites in fecal samples of cats in Andradina City, São Paulo. Rev Bras Parasitol Vet 2009, 18:46-49.

135. Verocai GG, Measures LN, Azevedo FD, Correia TR, Fernandes Jl, Scott FB: Dioctophyme renale (Goeze, 1782) in the abdominal cavity of a domestic cat from Brazil. Vet Parasitol 2009, 161:342-344.

136. Sobrinho LS, Rossi CN, Vides JP, Braga ET, Gomes AA, de Lima VM, Perri SH, Generoso D, Langoni H, Leutenegger C, Biondo AW, Laurenti MD, Marcondes M: Coinfection of Leishmania chagasi with Toxoplasma gondii, Feline Immunodeficiency Virus (FIV) and Feline Leukemia Virus (FeLV) in cats from an endemic area of zoonotic visceral leishmaniasis. Vet Parasitol 2012, 187:302-306.

137. Ramos DG, Scheremeta RG, Oliveira AC, Sinkoc AL, Pacheco R de C: Survey of helminth parasites of cats from the metropolitan area of Cuiabá, Mato Grosso, Brazil. Rev Bras Parasitol Vet 2013, 22:201-206.

138. Perez RR, Rubini AS, O'Dwyer LH: The first report of Hepatozoon spp. (Apicomplexa, Hepatozoidae) in domestic cats from São Paulo state, Brazil. Parasitol Res 2004, 94:83-85.

139. Savani ES, de Oliveira Camargo MC, de Carvalho MR, Zampieri RA, dos Santos MG, D'Auria SR, Shaw Jl, Floeter-Winter LM: The first record in the Americas of an autochthonous case of Leishmania (Leishmania) infantum chagasi in a domestic cat (Felix catus) from Cotia County, São Paulo State, Brazil. Vet Parasitol 2004, 120:229-233.
140. Schubach TM, Figueiredo FB, Pereira SA, Madeira MF, Santos IB, Andrade MV, Cuzzi T, Marzochi MC, Schubach A: American cutaneous leishmaniasis in two cats from Rio de Janeiro, Brazil: first report of natural infection with Leishmania (Viannia) braziliensis. Trans R Soc Trop Med Hyg 2004, 98:165-167.

141. Souza Al, Barros EM, Ishikawa E, Ilha IM, Marin GR, Nunes VL: Feline leishmaniasis due to Leishmania (Leishmania) amazonensis in Mato Grosso do Sul State, Brazil. Vet Parasitol 2005, 128:41-45.

142. Criado-Fornelio A, Ruas JL, Casado N, Farias NA, Soares MP, Müller G, Brumt JG, Berne ME, Buling-Saraña A, Barba-Carretero JC: New molecular data on mammalian Hepatozoon species (Apicomplexa: Adeleorina) from Brazil and Spain. J Parasitol 2006, 92:93-99.

143. Rubini AS, Dos Santos Paduan K, Perez RR, Ribolla PE, O'Dwyer LH: Molecular characterization of feline Hepatozoon species from Brazil. Vet Parasitol 2006, 137:168-171.

144. Coelho WM, Lima VM, Amarante AF, Langoni H, Pereira VB, Abdelnour A, Bresciani KD: Occurrence of Leishmania (Leishmania) chagasi in a domestic cat (Felis catus) in Andradina, São Paulo, Brazil: case report. Rev Bras Parasitol Vet 2010, 19:256-258.

145. Coelho WM, Richini-Pereira VB, Langoni H, Bresciani KD: Molecular detection of Leishmania sp. in cats (Felis catus) from Andradina Municipality, São Paulo State, Brazil. Vet Parasito/ 2011, 176:281-282.

146. de Bortoli CP, André MR, Braga Mdo S, Machado RZ: Molecular characterization of Hepatozoon sp. in cats from São Luís Island, Maranhão, Northeastern Brazil. Parasitol Res 2011, 109:1189-1192.

147. Vides JP, Schwardt TF, Sobrinho LS, Marinho M, Laurenti MD, Biondo AW, Leutenegger C, Marcondes M: Leishmania chagasi infection in cats with dermatologic lesions from an endemic area of visceral leishmaniosis in Brazil. Vet Parasitol 2011, 178:22-28.

148. Maia LM, Cerqueira AM, de Barros Macieira D, de Souza AM, Moreira NS, da Silva AV, Messick JB, Ferreira RF, Almosny NR: Cytauxzoon felis and 'Candidatus Mycoplasma haemominutum' coinfection in a Brazilian domestic cat (Felis catus). Rev Bras Parasitol Vet 2013, 22:289-291.

149. Coura-Vital W, Marques MJ, Veloso VM, Roatt BM, Aguiar-Soares RD, Reis LE, Braga SL, Morais MH, Reis AB, Carneiro M: Prevalence and factors associated with Leishmania infantum infection of dogs from an urban area of Brazil as identified by molecular methods. PLoS Neg/ Trop Dis 2011, 5:e1291.

150. Teles NM, Agostini MA, Bigeli JG, Noleto RV, Oliveira JD, de Oliveira Junior WD: Molecular and parasitological detection of Leishmania spp. in dogs caught in Palmas, TO, Brazil. Rev Bras Parasitol Vet 2012, 21:278-282.

151. Tomaz-Soccol V, Castro EA, Navarro IT, de Farias MR, de Souza LM, Carvalho Y, Bispo S, Membrive NA, Minozzo JC, Truppel J, Bueno W, Luz E: Allochthonous cases of canine visceral leishmaniasis in Paraná, Brazil: epidemiological implications. Rev Bras Parasitol Vet 2009, 18:46-51.

152. Marcondes CB, Pirmez C, Silva ES, Laurentino-Silva V, Steindel M, Santos AJ, Smaniotto $H$, Silva CF, Schuck Neto VF, Donetto A: A survey of visceral leishmaniasis in dogs from Santa Maria and neighbouring municipalities, State of Rio Grande do Sul. Rev Soc Bras Med Trop 2003, 36:499-501.

153. Salomón OD, Orellano PW: Lutzomyia longipalpis in Clorinda, Formosa province, an area of potential visceral leishmaniasis transmission in Argentina. Mem Inst Oswaldo Cruz 2005, 100:475-476.

154. Brazil RP, Caballero NN, Hamilton JG: Identification of the sex pheromone of Lutzomyia longipalpis (Lutz and Neiva, 1912) (Diptera: Psychodidae) from Asunción, Paraguay. Parasit Vectors 2009, 2:51.

155. Salomón OD, Basmajdian Y, Fernández MS, Santini MS: Lutzomyia longipalpis in Uruguay: the first report and the potential of visceral leishmaniasis transmission. Mem Inst Oswaldo Cruz 2011, 106:381-382.

156. Oliveira AG, Galati EA, de Oliveira O, de Oliveira GR, Espindola IA, Dorval ME, Brazil RP: Abundance of Lutzomyia longipalpis (Diptera: Psychodidae: Phlebotominae) and urban transmission of visceral leishmaniasis in Campo Grande, state of Mato Grosso do Sul, Brazil. Mem Inst Oswaldo Cruz 2006, 101:869-874.

157. Souza GD, Santos E, Andrade Filho JD: The first report of the main vector of visceral leishmaniasis in America, Lutzomyia longipalpis (Lutz \& Neiva) (Diptera: Psychodidae: Phlebotominae), in the state of Rio Grande do Sul, Brazil. Mem Inst Oswaldo Cruz 2009, 104:1181-1182.

158. Loretti AP, Barros SS: Hemorrhagic disease in dogs infected with an unclassified intraendothelial piroplasm in southern Brazil. Vet Parasitol 2005, 134:193-213.

159. Silva AS, Martins DB, Soares JF, França RT: Canine rangeliosis: the need for differential diagnosis. Parasitol Res 2013, 112:1329-1332. 
160. Szabó MP, Pinter A, Labruna MB: Ecology, biology and distribution of spotted-fever tick vectors in Brazil. Front Cell Infect Microbiol 2013, 3:27.

161. Burlini L, Teixeira KR, Szabó MP, Famadas KM: Molecular dissimilarities of Rhipicephalus sanguineus (Acari: Ixodidae) in Brazil and its relation with samples throughout the world: is there a geographical pattern? Exp App/ Acarol 2010, 50:361-374.

162. Moraes-Filho J, Marcili A, Nieri-Bastos FA, Richtzenhain LJ, Labruna MB: Genetic analysis of ticks belonging to the Rhipicephalus sanguineus group in Latin America. Acta Trop 2011, 117:51-55.

163. Alves LC, de Almeida Silva LV, Faustino MA, McCall JW, Supakonderj P, Labarthe NW, Sanchez M, Caires O: Survey of canine heartworm in the city of Recife, Pernambuco, Brazil. Mem Inst Oswaldo Cruz 1999, 94:587-590.

164. Brito AC, Vila-Nova MC, Martins Rocha DA, Gomes Costa L, de Almeida WA P, da Silva Viana L, Ramalho Lopes R Jr, Fontes G, da Rocha EM, Regis L: Prevalence of canine filariasis by Dirofilaria immitis and Dipetalonema reconditum in Maceió, Alagoas State, Brazil. Cad Saude Publica 2001, 17:1497-504.

165. Linardi PM: Endoparasitos de Ctenocephalides felis felis (Siphonaptera: Pulicidae) em Belo Horizonte, MG. Biogeosciences 2002, 64:65.

166. Reifur L, Thomaz-Soccol V, Montiani-Ferreira F: Epidemiological aspects of filariosis in dogs on the coast of Paraná state, Brazil: with emphasis on Dirofilaria immitis. Vet Parasitol 2004, 122:273-286.

167. Avelar DM, Bussolotti AS, do Carmo A A, Ramos M M, Linardi PM: Endosymbionts of Ctenocephalides felis felis (Siphonaptera: Pulicidae) obtained from dogs captured in Belo Horizonte, Minas Gerais, Brazil. J Invertebr Pathol 2007, 94:149-152.

168. Dantas-Torres F, de Brito ME, Brandão-Filho SP: Seroepidemiological survey on canine leishmaniasis among dogs from an urban area of Brazil. Vet Parasitol 2006, 140:54-60

169. Figueredo LA, Dantas-Torres F, de Faria EB, Gondim LF, Simões-Mattos L, Brandão-Filho SP, Mota RA: Occurrence of antibodies to Neospora caninum and Toxoplasma gondii in dogs from Pernambuco, Northeast Brazil. Vet Parasitol 2008, 157:9-13.

170. Santos JM, Dantas-Torres F, Mattos MR, Lino FR, Andrade LS, Souza RC, Brito FL, Brito ME, Brandão-Filho SP, Simões-Mattos L: Prevalence of anti-Leishmania spp antibodies in dogs from Garanhuns, in the middle scrub zone (Agreste) of Pernambuco. Rev Soc Bras Med Trop 2010, 43:41-45.

171. Coelho WM, do Amarante AF, Apolinário JC, Coelho NM, de Lima VM, de Perri SH, de Bresciani KD: Seroepidemiology of Toxoplasma gondii, Neospora caninum, and Leishmania spp. infections and risk factors for cats from Brazil. Parasitol Res 2011, 109:1009-1013.

172. Cardia DF, Camossi LG, Neto LD, Langoni H, Bresciani KD: Prevalence of Toxoplasma gondii and Leishmania spp. infection in cats from Brazil. Vet Parasitol 2013, 197:634-637.

173. Nogueira Cl, Mesquita LP, Abreu CC, Nakagaki KY, Seixas JN, Bezerra PS, Rocha CM, Guimaraes AM, Peconick AP, Varaschin MS: Risk factors associated with seroprevalence of Neospora caninum in dogs from urban and rural areas of milk and coffee production in Minas Gerais state, Brazil. Epidemiol Infect 2013, 141:2286-2293.

174. Labarthe N, Serrão ML, Melo YF, de Oliveira SJ, Lourenço-de-Oliveira R: Mosquito frequency and feeding habits in an enzootic canine dirofilariasis area in Niterói, state of Rio de Janeiro, Brazil. Mem Inst Oswaldo Cruz 1998, 93:145-154.

175. Resende MC, Camargo MC, Vieira JR, Nobi RC, Porto MN, Oliveira CD Pessanha JE, Cunha Mda C, Brandão ST: Seasonal variation of Lutzomyia longipalpis in Belo Horizonte, State of Minas Gerais. Rev Soc Bras Med Trop 2006, 39:51-55.

176. Ximenes MF, Castellón EG, De Souza MF, Menezes AA, Queiroz JW, Macedo e Silva VP, Jerônimo SM: Effect of abiotic factors on seasonal population dynamics of Lutzomyia longipalpis (Diptera: Psychodidae) in northeastern Brazil. J Med Entomol 2006, 43:990-995.

177. Oliveira AG, Galati EA, Fernandes CE, Dorval ME, Brazil RP: Seasonal variation of Lutzomyia longipalpis (Lutz \& Neiva, 1912) (Diptera: Psychodidae: Phlebotominae) in endemic area of visceral leishmaniasis, Campo Grande, state of Mato Grosso do Sul, Brazil. Acta Trop 2008, 105:55-61

178. Amóra SS, Bevilaqua CM, Dias EC, Feijó FM, Oliveira PG, Peixoto GC, Alves ND, Oliveira LM, Macedo IT: Monitoring of Lutzomyia longipalpis Lutz \& Neiva, 1912 in an area of intense transmission of visceral leishmaniasis in Rio Grande do Norte, Northeast Brazil. Rev Bras Parasitol Vet 2010, 19:39-43.
179. Saraiva L, Andrade Filho JD, Falcão AL, de Carvalho DA, de Souza CM, Freitas CR, Gomes Lopes CR, Moreno EC, Melo MN: Phlebotominae fauna (Diptera: Psychodidae) in an urban district of Belo Horizonte, Brazil, endemic for visceral leishmaniasis: characterization of favored locations as determined by spatial analysis. Acta Trop 2011, 117:137-145.

180. Costa PL, Dantas-Torres F, da Silva FJ, Guimarães VC, Gaudêncio K, BrandãoFilho SP: Ecology of Lutzomyia longipalpis in an area of visceral leishmaniasis transmission in north-eastern Brazil. Acta Trop 2013, 126:99-102.

181. Reinhold-Castro KR, Fenelon VC, Rossi RM, Brito JE, Freitas JS, Teodoro U: Impact of control measures and dynamics of sand flies in southern Brazil. J Vector Ecol 2013, 38:63-68.

182. Silveira JA, Passos LM, Ribeiro MF: Population dynamics of Rhipicephalus sanguineus (Latrielle, 1806) in Belo Horizonte, Minas Gerais state, Brazil. Vet Parasitol 2009, 161:270-275.

183. Louly CCB, Fonseca IN, Oliveira VF, Linhares GFC, Menezes LB, Borges LMF: Seasonal dynamics of Rhipicephalus sanguineus (Acari: Ixodidae) in dogs from a police unit in Goiania, Goias, Brazil. Cienc Rural 2007, 37:464-469.

184. Maia MG, Costa RT, Haddad JP, Passos LM, Ribeiro MF: Epidemiological aspects of canine babesiosis in the semiarid area of the state of Minas Gerais, Brazil. Prev Vet Med 2007, 79:155-162.

185. Heukelbach J, Jackson A, Ariza L, Feldmeier H: Prevalence and risk factors of hookworm-related cutaneous larva migrans in a rural community in Brazil. Ann Trop Med Parasitol 2008, 102:53-61.

186. Tiyo R, Guedes TA, Falavigna DL, Falavigna-Guilherme AL: Seasonal contamination of public squares and lawns by parasites with zoonotic potential in southern Brazil. J Helminthol 2008, 82:1-6.

187. Andresiuk V, Sardella N, Denegri G: Seasonal fluctuations in prevalence of dog intestinal parasites in public squares of Mar del Plata city, Argentina and its risk for humans. Rev Argent Microbiol 2007, 39:221-224.

188. Táparo CV, Perri SHV, Serrano ACM, Ishizaki MN, Costa TP, Amarante AFT, Bresciani KDS: Comparison between coproparasitological techniques for the diagnosis of helminth eggs or protozoa oocysts in dogs. Rev Bras Parasitol Vet 2006, 15:1-5

189. Mandarino-Pereira A, de Souza FS, Lopes CW, Pereira MJ: Prevalence of parasites in soil and dog feces according to diagnostic tests. Vet Parasitol 2010, 170:176-181

190. Katagiri S, Oliveira-Sequeira TC: Comparison of three concentration methods for the recovery of canine intestinal parasites from stool samples. Exp Parasitol 2010, 126:214-216.

191. Gomes JF, Hoshino-Shimizu S, Dias LC, Araujo AJ, Castilho VL, Neves FA: Evaluation of a novel kit (TF-Test) for the diagnosis of intestinal parasitic infections. J Clin Lab Anal 2004, 18:132-138.

192. Farias LN, Malgor R, Cassaravilla C, Bragança C, de la Rue ML: Echinococcosis in southern Brazil: efforts toward implementation of a control program in Santana do Livramento, Rio Grande do Sul. Rev Inst Med Trop Sao Paulo 2004, 46:153-156

193. Monteiro RM, Pena HF, Gennari SM, de Souza SO, Richtzenhain LJ, Soares RM: Differential diagnosis of oocysts of Hammondia-like organisms of dogs and cats by PCR-RFLP analysis of 70-kilodalton heat shock protein (HSP70) gene. Parasitol Res 2008, 103:235-238.

194. Soares RM, Lopes EG, Keid LB, Sercundes MK, Martins J, Richtzenhain LJ: Identification of Hammondia heydorni oocysts by a heminested-PCR (hnPCR-AP10) based on the $H$. heydorni RAPD fragment AP10. Vet Parasitol 2011, 175:168-172.

195. Dantas-Torres F, Figueredo LA: Canine babesiosis: a Brazilian perspective. Vet Parasitol 2006, 141:197-203.

196. Trapp SM, Dagnone AS, Vidotto O, Freire RL, Amude AM, de Morais HS: Seroepidemiology of canine babesiosis and ehrlichiosis in a hospital population. Vet Parasitol 2006, 140:223-230.

197. Guimarães AM, Rocha CM, Oliveira TM, Rosado IR, Morais LG, Santos RR: Factors associated the seropositivity for Babesia, Toxoplasma, Neospora e Leishmania in dogs attended at nine veterinary clinics in the municipality of Lavras. MG. Rev Bras Parasitol Vet 2009, 18(Suppl 1):49-53.

198. Furuta PI, Oliveira TM, Theixeira MC, Rocha AG, Machado RZ, Tinucci-Costa MG: Comparison between a soluble antigen-based ELISA and IFAT in detecting antibodies against Babesia canis in dogs. Rev Bras Parasitol Vet 2009, 18:41-45.

199. Ramos R, Ramos C, Araújo F, Oliveira R, Souza I, Pimentel D, Galindo M Santana M, Rosas E, Faustino M, Alves L: Molecular survey and genetic characterization of tick-borne pathogens in dogs in metropolitan Recife (north-eastern Brazil). Parasitol Res 2010, 107:1115-1120. 
200. Almeida AB, Sousa VR, Gasparetto ND, da Silva GF, Figueiredo FB, Dutra V, Nakazato L, Madeira MF: Canine visceral leishmaniasis: diagnostic approaches based on polymerase chain reaction employing different biological samples. Diagn Microbiol Infect Dis 2013, 76:321-324.

201. Ferreira SA, Almeida GG, Silva SO, Vogas GP, Fujiwara RT, de Andrade AS, Melo MN: Nasal, oral and ear swabs for canine visceral leishmaniasis diagnosis: new practical approaches for detection of Leishmania infantum DNA. PLoS Negl Trop Dis 2013, 7:e2150.

202. Paiva Cavalcanti M, Dantas-Torres F, da Cunha G, de Albuquerque S, Silva de Morais RC, de Brito ME, Otranto D, Brandão-Filho SP: Quantitative real time PCR assays for the detection of Leishmania (Viannia) braziliensis in animals and humans. Mol Cell Probes 2013, 27:122-128.

203. Reis LE, Coura-Vital W, Roatt BM, Bouillet LE, Ker HG, de Brito RC F, Resende DD, Carneiro M, Giunchetti RC, Marques MJ, Carneiro CM, Reis AB: Molecular diagnosis of canine visceral leishmaniasis: a comparative study of three methods using skin and spleen from dogs with natural Leishmania infantum infection. Vet Parasitol 2013, 197:498-503.

204. Silva MA, Pedrosa Soares CR, Medeiros RA, Medeiros Z, de Melo FL: Optimization of single-tube nested PCR for the diagnosis of visceral leishmaniasis. Exp Parasitol 2013, 134:206-210.

205. Madeira MF, de O Schubach A, Schubach TM, Pereira SA, Fiqueiredo FB, Baptista C, Leal CA, Melo CX, Confort EM, Marzochi MC: Post mortem parasitological evaluation of dogs seroreactive for Leishmania from Rio de Janeiro, Brazil. Vet Parasitol 2006, 138:366-370.

206. Silva DA, Madeira MF, Teixeira AC, de Souza CM, Figueiredo FB: Laboratory tests performed on Leishmania seroreactive dogs euthanized by the leishmaniasis control program. Vet Parasitol 2011, 179:257-261.

207. Cavalcanti A, Lobo R, Cupolillo E, Bustamante F, Porrozzi R: Canine cutaneous leishmaniasis caused by neotropical Leishmania infantum despite of systemic disease: a case report. Parasitol Int 2012, 61:738-740.

208. Souza Al, Nunes VLB, Borralho VM, Ishikawa EAY: Domestic feline cutaneous leishmaniasis in the municipality of Ribas do Rio Pardo, Mato Grosso do Sul state, Brazil: a case report. J Venom Anim Toxins ind Trop Dis 2009, 15:359-365.

209. Demeler J, Ramünke S, Wolken S, laniello D, Rinaldi L, Gahutu JB, Cringoli G, von Samson-Himmelstjerna G, Krücken J: Discrimination of gastrointestinal nematode eggs from crude fecal egg preparations by inhibitor-resistant conventional and real-time PCR. PLoS One 2013, 8:e61285.

210. Deplazes P, van Knapen F, Schweiger A, Overgaauw PA: Role of pet dogs and cats in the transmission of helminthic zoonoses in Europe, with a focus on echinococcosis and toxocarosis. Vet Parasitol 2011, 182:41-53.

211. Lucio-Forster A, Liotta JL, Yaros JP, Briggs KR, Mohammed HO, Bowman DD: Morphological differentiation of eggs of Ancylostoma caninum, Ancylostoma tubaeforme, and Ancylostoma braziliense from dogs and cats in the United States. J Parasitol 2012, 98:1041-1044.

212. Taylor MA: Recent developments in ectoparasiticides. Vet J 2001 161:253-268.

213. Wall R: Ectoparasites: future challenges in a changing world. Vet Parasito 2007, 148:62-74.

214. Pollmeier M, Pengo G, Jeannin P, Soll M: Evaluation of the efficacy of fipronil formulations in the treatment and control of biting lice, Trichodectes canis (De Geer, 1778) on dogs. Vet Parasitol 2002, 107:127-136.

215. Stanneck D, Kruedewagen EM, Fourie JJ, Horak IG, Davis W, Krieger KJ: Efficacy of an imidacloprid/flumethrin collar against fleas, ticks, mites and lice on dogs. Parasit Vectors 2012, 5:102.

216. Kužner J, Turk S, Grace S, Soni-Gupta J, Fourie JJ, Marchiondo AA, Rugg D: Confirmation of the efficacy of a novel fipronil spot-on for the treatment and control of fleas, ticks and chewing lice on dogs. Vet Parasitol 2013 193:245-251.

217. Serra-Freire NM, Benigno RNM, Oliveira SA, Lopes LMS, Galvão G: Lynxacarus radovskyi - diagnostic and treatment in cats from the Metropolitan region of Belem City, Para State. Rev Universidade Rural, Série Ciências da Vida 2002, 22:57-60

218. Franco MB, Hamann W: Doramectin in the treatment of dogs with sarcoptic mange and gastrintestinal nematodes. Arch Vet Sci 2004 9:23-29.

219. Silva RPB, Belettini ST, Stel RF, Martins LA, Pachaly JR: Canine dermodicosis and new treatment perspectives: review. Arq Cienc Vet Zool Unipar 2008, 11:139-151

220. Otranto D, Wall R: New strategies for the control of arthropod vectors of disease in dogs and cats. Med Vet Entomol 2008, 22:291-302.
221. Paz GF, Labruna MB, Leite RC: Drop off rhythm of Rhipicephalus sanguineus (Acari: Ixodidae) of artificially infested dogs. Rev Bras Parasitol Vet 2008, 17:139-144.

222. Blagburn BL, Dryden MW: Biology, treatment, and control of flea and tick infestations. Vet Clin North Am Small Anim Pract 2009, 39:1173-1200.

223. Oliveira Lima JW, de Góes Cavalcanti LP, Pontes RJ, Heukelbach J: Survival of Betta splendens fish (Regan, 1910) in domestic water containers and its effectiveness in controlling Aedes aegypti larvae (Linnaeus, 1762) in Northeast Brazil. Trop Med Int Health 2010, 15:1525-1532.

224. Barbosa RM, Regis LN: Monitoring temporal fluctuations of Culex quinquefasciatus using oviposition traps containing attractant and larvicide in an urban environment in Recife, Brazil. Mem Inst Oswaldo Cruz 2011, 106:451-415.

225. da Saúde M: Manual de vigilância e controle da leishmaniose visceral. Brasília: Ministério da Saúde; 2006.

226. da Saúde M: Manual de Vigilância da leishmaniose tegumentar americana. 2ath edition. Brasília: Ministério da Saúde; 2007.

227. Alexander B, Barros VC, de Souza SF, Barros SS, Teodoro LP, Soares ZR, Gontijo NF, Reithinger R: Susceptibility to chemical insecticides of two Brazilian populations of the visceral leishmaniasis vector Lutzomyia longipalpis (Diptera: Psychodidae). Trop Med Int Health 2009, 14:1272-1277.

228. Belinato TA, Martins AJ, Valle D: Fitness evaluation of two Brazilian Aedes aegypti field populations with distinct levels of resistance to the organophosphate temephos. Mem Inst Oswaldo Cruz 2012, 107:916-922.

229. Courtenay O, Gillingwater K, Gomes PA, Garcez LM, Davies CR: Deltamethrin-impregnated bednets reduce human landing rates of sandfly vector Lutzomyia longipalpis in Amazon households. Med Vet Entomol 2007, 21:168-176.

230. Araujo JM, Araújo JV, Braga FR, Araújo DM, Ferreira SR, Soares FE, Benjamin LA: Survival of Pochonia chlamydosporia in the gastrointestinal tract of experimentally treated dogs. Res Vet Sci 2012, 93:803-806.

231. Otranto D, Dantas-Torres F: The prevention of canine leishmaniasis and its impact on public health. Trends Parasitol 2013, 29:339-345.

232. Dantas-Torres F, Latrofa MS, Weigl S, Tarallo VD, Lia RP, Otranto D: Hepatozoon canis infection in ticks during spring and summer in Italy. Parasitol Res 2012, 110:695-698.

233. Giannelli A, Ramos RA, Di Paola G, Mencke N, Dantas-Torres F, Baneth G, Otranto D: Transstadial transmission of Hepatozoon canis from larvae to nymphs of Rhipicephalus sanguineus. Vet Parasitol 2013, 196:1-5.

234. Dantas-Torres F: Canine leishmaniosis in South America. Parasit Vectors 2009, 2(Suppl 1):S1

235. Bongiorno G, Paparcone R, Manzillo VF, Oliva G, Cuisinier AM, Gradoni L: Vaccination with LiESP/QA-21 (CaniLeish ${ }^{\oplus}$ ) reduces the intensity of infection in Phlebotomus perniciosus fed on Leishmania infantum infected dogs-A preliminary xenodiagnosis study. Vet Parasitol 2013, 197:691-695.

236. Otranto D, de Caprariis D, Lia RP, Tarallo V, Lorusso V, Testini G, DantasTorres F, Latrofa S, Diniz PP, Mencke N, Maggi RG, Breitschwerdt E, Capelli G, Stanneck D: Prevention of endemic canine vector-borne diseases using imidacloprid $10 \%$ and permethrin $50 \%$ in young dogs: a longitudinal field study. Vet Parasitol 2010, 172:323-332.

237. Dantas-Torres F, Capelli G, Giannelli A, Ramos RA, Lia RP, Cantacessi C, de Caprariis D, De Tommasi AS, Latrofa MS, Lacasella V, Tarallo VD, Di Paola G Qurollo B, Breitschwerdt E, Stanneck D, Otranto D: Efficacy of an imidacloprid/flumethrin collar against fleas, ticks and tick-borne pathogens in dogs. Parasit Vectors 2013, 6:245

238. Otranto D, Dantas-Torres F, de Caprariis D, Di Paola G, Tarallo VD, Latrofa MS, Lia RP, Annoscia G, Breitshwerdt EB, Cantacessi C, Capelli G, Stanneck D: Prevention of canine leishmaniosis in a hyper-endemic area using a combination of 10\% imidacloprid/4.5\% flumethrin. PLoS One 2013, 8:e56374.

239. Beugnet F, Franc M: Insecticide and acaricide molecules and/or combinations to prevent pet infestation by ectoparasites. Trends Parasitol 2012, 28:267-279.

240. Beugnet F, Delport P, Luus H, Crafford D, Fourie J: Preventive efficacy of Frontline $\left({ }^{\oplus}\right)$ Combo and Certifect $\left({ }^{\oplus}\right)$ against Dipylidium caninum infestation of cats and dogs using a natural flea (Ctenocephalides felis) infestation model. Parasite 2013, 20:7.

241. Fourie JJ, Ollagnier C, Beugnet F, Luus HG, Jongejan F: Prevention of transmission of Ehrlichia canis by Rhipicephalus sanguineus ticks to dogs treated with a combination of fipronil, amitraz and (S)-methoprene (CERTIFECT ${ }^{\oplus}$ ). Vet Parasitol 2013, 193:223-228. 
242. Dantas-Torres F, Figueredo LA, Brandão-Filho SP: Rhipicephalus sanguineus (Acari: Ixodidae), the brown dog tick, parasitizing humans in Brazil. Rev Soc Bras Med Trop 2006, 39:64-67.

243. Guglielmone AA, Beati L, Barros-Battesti DM, Labruna MB, Nava S, Venzal JM, Mangold AJ, Szabó MP, Martins JR, González-Acuña D, Estrada-Peña A: Ticks (Ixodidae) on humans in South America. Exp Appl Acarol 2006, 40:83-100.

244. Louly CCB, Fonseca IN, Oliveira VF, Borges LMF: Occurrence of Rhipicephalus sanguineus in workers of veterinary clinics and kennels from Goiânia county, Goiás, Brazil. Cienc Anim Bras 2006, 7:103-106.

245. Szabó MP, Labruna MB, Castagnolli KC, Garcia MV, Pinter A, Veronez VA, Magalhães GM, Castro MB, Vogliotti A: Ticks (Acari: Ixodidae) parasitizing humans in an Atlantic rainforest reserve of Southeastern Brazil with notes on host suitability. Exp Appl Acarol 2006, 39:339-346.

246. Serra-Freire NM: Occurrence of ticks (Acari: Ixodidae) on human hosts, in three municipalities in the State of Pará, Brazil. Rev Bras Parasitol Vet 2010, 19:141-147.

247. Borsoi ABP, Serra-Freire NM: Parasitic relations between human beings and ticks in the Volta Redonda city, state of Rio de Janeiro, Brazil. Rev UNIABEU 2012, 5:306-317.

248. Dantas-Torres F: Rocky Mountain spotted fever. Lancet Infect Dis 2007, 7:724-732

249. Perez M, Bodor M, Zhang C, Xiong Q, Rikihisa Y: Human infection with Ehrlichia canis accompanied by clinical signs in Venezuela. Ann N Y Acad Sci 2006, 1078:110-117.

250. Vieira RF, Vieira TS, Nascimento DA, Martins TF, Krawczak FS, Labruna MB, Chandrashekar R, Marcondes M, Biondo AW, Vidotto O: Serological survey of Ehrlichia species in dogs, horses and humans: zoonotic scenery in a rural settlement from southern Brazil. Rev Inst Med Trop Sao Paulo 2013, 55:335-340

251. Saito TB, Cunha-Filho NA, Pacheco RC, Ferreira F, Pappen FG, Farias NA, Larsson CE, Labruna MB: Canine infection by rickettsiae and ehrlichiae in southern Brazil. Am J Trop Med Hyg 2008, 79:102-108.

252. Santos F, Coppede JS, Pereira AL, Oliveira LP, Roberto PG, Benedetti RB, Zucoloto LB, Lucas F, Sobreira L, Marins M: Molecular evaluation of the incidence of Ehrlichia canis, Anaplasma platys and Babesia spp. in dogs from Ribeirão Preto, Brazil. Vet J 2009, 179:145-148.

253. Silva JN, Almeida AB, Boa Sorte Eda C, Freitas AG, Santos LG, Aguiar DM, Sousa VR: Seroprevalence anti-Ehrlichia canis antibodies in dogs of Cuiabá, Mato Grosso. Rev Bras Parasitol Vet 2010, 19:108-111.

254. Souza BM, Leal DC, Barboza DC, Uzêda RS, De Alcântara AC, Ferreira F, Labruna MB: Prevalence of ehrlichial infection among dogs and ticks in Northeastern Brazil. Rev Bras Parasitol Vet 2010, 19:89-93.

255. Aguiar DM, Cavalcante GT, Pinter A, Gennari SM, Camargo LM, Labruna MB: Prevalence of Ehrlichia canis (Rickettsiales: Anaplasmataceae) in dogs and Rhipicephalus sanguineus (Acari: Ixodidae) ticks from Brazil. J Med Entomol 2007, 44:126-132.

256. Dantas-Torres F: The brown dog tick, Rhipicephalus sanguineus (Latreille, 1806) (Acari: Ixodidae): from taxonomy to control. Vet Parasitol 2008 152:173-185.

257. Limongi JE, Silva JJ, Paula MBC, Mendes J: Epidemiologic aspects of flea infestations in the urban area of Uberlândia, Minas Gerais, 2007-2010. Epidemiol Serv Saude 2013, 22:285-294.

258. Oliveira RP, Galvão MA, Mafra CL, Chamone CB, Calic SB, Silva SU, Walker $\mathrm{DH}$ : Rickettsia felis in Ctenocephalides spp. fleas, Brazil. Emerg Infect Dis 2002, 8:317-319.

259. Parola P: Rickettsia felis: from a rare disease in the USA to a common cause of fever in sub-Saharan Africa. Clin Microbiol Infect 2011, 17:996-1000.

260. Traversa D: Pet roundworms and hookworms: a continuing need for global worming. Parasit Vectors 2012, 5:91

261. Vidal JE, Sztajnbok J, Seguro AC: Eosinophilic meningoencephalitis due to Toxocara canis: case report and review of the literature. Am J Trop Med Hyg 2003, 69:341-343.

262. Moreira-Silva SF, Rodrigues MG, Pimenta JL, Gomes CP, Freire LH, Pereira FE: Toxocariasis of the central nervous system: with report of two cases. Rev Soc Bras Med Trop 2004, 37:169-174.

263. Musso C, Castelo JS, Tsanaclis AM, Pereira FE: Prevalence of Toxocarainduced liver granulomas, detected by immunohistochemistry, in a series of autopsies at a Children's Reference Hospital in Vitoria, ES, Brazil. Virchows Arch 2007, 450:411-417.

264. Schuster A, Lesshafft $H$, Reichert $F$, Talhari $S$, de Oliveira SG, Ignatius $R$, Feldmeier $\mathrm{H}$ : Hookworm-related cutaneous larva migrans in northern
Brazil: resolution of clinical pathology after a single dose of ivermectin. Clin Infect Dis 2013, 57:1155-1157.

265. Fragoso RP, Monteiro MB, Lemos EM, Pereira FE: Anti-Toxocara antibodies detected in children attending elementary school in Vitoria, State of Espírito Santo, Brazil: prevalence and associated factors. Rev Soc Bras Med Trop 2011, 44:461-466.

266. Souza RF, Dattoli VC, Mendonça LR, Jesus JR, Baqueiro T, Santana Cde C, Santos NM, Barrouin-Melo SM, Alcantara-Neves NM: Prevalence and risk factors of human infection by Toxocara canis in Salvador, State of Bahia, Brazil. Rev Soc Bras Med Trop 2011, 44:516-519.

267. Mattia S, Colli CM, Adami CM, Guilherme GF, Nishi L, Rubinsky-Elefant G, Marchioro AA, Gomes ML, Falavigna-Guilherme AL: Seroprevalence of Toxocara infection in children and environmental contamination of urban areas in Paraná State, Brazil. J Helminthol 2012, 86:440-445.

268. Mendonça LR, Veiga RV, Dattoli VC, Figueiredo CA, Fiaccone R, Santos J, Cruz ÁA, Rodrigues LC, Cooper PJ, Pontes-de-Carvalho LC, Barreto ML, Alcantara-Neves NM: Toxocara seropositivity, atopy and wheezing in children living in poor neighbourhoods in urban Latin American. PLoS Negl Trop Dis 2012, 6:e1886.

269. Schoenardie ER, Scaini CJ, Brod CS, Pepe MS, Villela MM, McBride AJ, Borsuk S, Berne ME: Seroprevalence of Toxocara infection in children from southern Brazil. J Parasitol 2013, 99:537-539.

270. Capuano DM, Rocha GM: Environmental contamination by Toxocara sp. eggs in Ribeirão Preto, São Paulo State, Brazil. Rev Inst Med Trop Sao Paulo 2005, 47:223-226.

271. Cassenote AJ, Pinto Neto JM, Lima-Catelani AR, Ferreira AW: Soil contamination by eggs of soil-transmitted helminths with zoonotic potential in the town of Fernandópolis, State of São Paulo, Brazil, between 2007 and 2008. Rev Soc Bras Med Trop 2011, 44:371-374

272. Gallina T, Silva MA, Castro LL, Wendt EW, Villela MM, Berne ME: Presence of eggs of Toxocara spp. and hookworms in a student environment in Rio Grande do Sul, Brazil. Rev Bras Parasitol Vet 2011, 20:176-177.

273. Marques JP, Guimarães CR, Boas AV, Carnaúba PU, Moraes J: Contamination of public parks and squares from Guarulhos (São Paulo State, Brazil) by Toxocara spp. and Ancylostoma spp. Rev Inst Med Trop Sao Paulo 2012, 54:267-271.

274. Marchioro AA, Colli CM, Ferreira EC, Tiyo R, Mattia S, de Souza WF, Falavigna-Guilherme AL: Identification of public areas with potential toxocariasis transmission risk using Geographical Information Systems. Acta Parasitol 2013, 58:328-333.

275. Artigas PT, Araújo P, Romiti N, Ruivo M: Sobre um caso de parasitismo humano por Lagochilascaris minor Leiper, 1909, no Estado de São Paulo, Brasil. Rev Inst Med Trop Sao Paulo 1968, 10:78-83.

276. Veloso MG, Faria MC, de Freitas JD, Moraes MA, Gorini DF, de Mendonça JL: Human lagochilascariasis. 3 cases encountered in the Federal District, Brazil. Rev Inst Med Trop Sao Paulo 1992, 34:587-591.

277. Aguilar-Nascimento JE, Silva GM, Tadano T, Valadares Filho M, Akiyama AM, Castelo A: Infection of the soft tissue of the neck due to Lagochilascaris minor. Trans R Soc Trop Med Hyg 1993, 87:198.

278. Vieira MA, de Oliveira JA, Ferreira LS, de Oliveira V, Barbosa CA: A case report of human lagochilascariasis coming from Pará State, Brazil. Rev Soc Bras Med Trop 2000, 33:87-90.

279. Aquino RT, Magliari ME, Vital Filho J, Silva MA, Lima CA, Rocha AJ, Silva CJ, Rewin JA, Nahas TR, Chieffi PP: Lagochilascariasis leading to severe involvement of ocular globes, ears and meninges. Rev Inst Med Trop Sao Paulo 2008, 50:355-358.

280. Palheta-Neto FX, Leão RNQ, Neto HF, Tomita S, Lima MAMT, Pezzin-Palheta AC: Contribution to the study of human lagochilascariasis. Rev Bras Otorrinolaringol 2002, 68:101-105.

281. Amato JF, Grisi L, Pimentel Neto M: Two cases of fistulated abscesses caused by Lagochilascaris major in the domestic cat. Mem Inst Oswaldo Cruz 1990, 85:471-473.

282. Sudré AP, Uchôa F, Brener B: Lagochilascariasis in a housecat and the potential risk for human disease. Braz J Infect Dis 2012, 16:111-112.

283. Faccio L, Oliveira CB, Denardin CA, Tonin AA, Gressler LT, Dalla Rosa L, Sampaio LC, Stainki DR, Monteiro SG: Case report: Feline infection by Lagochilascaris sp. in the State of Rio Grande do Sul, Brazil. Vet Parasitol 2013, 196:541-543.

284. Barbosa CAL, Barbosa AP, Campos DMB: Domestic cat (Felis catus domesticus) as a possible reservoir of Lagochilascaris minor Leiper, 1909. Rev Patol Trop 2005, 34:205-211. 
285. Moura MQ, Jeske S, Gallina T, Borsuk S, Berne ME, Villela MM: First report of Lagochilascaris (Nematoda: Ascarididae) eggs in a public park in Southern Brazil. Vet Parasitol 2012, 184:359-361.

286. Marinho RP, Neves DP: Dipylidium caninum (Dilepididae-Cestoda). Report of 2 human cases. Rev Inst Med Trop Sao Paulo 1979, 21:266-268.

287. Lemos CH, Oliveira CR: Infestação humana pelo Dipylidium caninum. Rev Soc Bras Med Trop 1985, 18:267-268.

288. Maia MA, Campos DMB, Damasceno FA: Dipylidium caninum (CestodaDilepididae). Report of one human case in Goiânia, Goiás, Brazil. Rev Patol Trop 1991, 20:7-12.

289. Larrieu E, Zanini F: Critical analysis of cystic echinococcosis control programs and praziquantel use in South America, 1974-2010. Rev Panam Salud Publica 2012, 31:81-87.

290. de la Rue ML: Cystic echinococcosis in southern Brazil. Rev Inst Med Trop Sao Paulo 2008, 50:53-56.

291. Moraes MA, Sobreira MN, Medeiros Filho P, Tavares AC, Gomes Ml: Polycystic hydatidosis: casual finding of calcified hydatid cyst simulating mesenteric neoplasm. Rev Soc Bras Med Trop 2003, 36:519-521.

292. D'Alessandro A, Rausch RL: New aspects of neotropical polycystic (Echinococcus vogeli) and unicystic (Echinococcus oligarthrus) echinococcosis. Clin Microbiol Rev 2008, 21:380-401.

293. Eckert J, Deplazes P: Biological, epidemiological, and clinical aspects of echinococcosis, a zoonosis of increasing concern. Clin Microbiol Rev 2004 17:107-135

294. Dantas-Torres F, Otranto D: Dirofilariosis in the Americas: a more virulent Dirofilaria immitis? Parasit Vectors 2013, 6:288.

295. de Campos JR M, Barbas CS, Filomeno LT, Fernandez A, Minamoto H, Filho $J V$, Jatene FB: Human pulmonary dirofilariasis: analysis of 24 cases from São Paulo, Brazil. Chest 1997, 112:729-733.

296. Rodrigues-Silva R, Moura H, Dreyer G, Rey L: Human pulmonary dirofilariasis: a review. Rev Inst Med Trop Sao Paulo 1995, 37:523-530

297. Cavallazzi R, Cavallazzi A, Souza I, Cardoso J: Dirofilariose pulmonar humana: relato de sete casos. J Pneumol 2002, 28:100-102.

298. Rodrigues-Silva R, Guerra RJ, de Almeida FB, Machado-Silva JR, de Paiva DD: Human pulmonary dirofilariasis at Rio de Janeiro, Brazil: a case report. Rev Soc Bras Med Trop 2004, 37:56-59.

299. Otranto D, Diniz DG, Dantas Torres F, Casiraghi M, De Almeida IN, De Almeida LN, Dos Santos JN, Furtado AP, De Almeida Sobrinho EF, Bain O: Human intraocular filariasis caused by Dirofilaria sp. nematode, Brazil. Emerg Infect Dis 2011, 17:863-866.

300. Dantas-Torres F, Solano-Gallego L, Baneth G, Ribeiro VM, de Paiva-Cavalcanti M, Otranto D: Canine leishmaniosis in the Old and New Worlds: unveiled similarities and differences. Trends Parasitol 2012, 28:531-538.

301. Maia-Elkhoury AN, Alves WA, Sousa-Gomes ML, Sena JM, Luna EA: Visceral leishmaniasis in Brazil: trends and challenges. Cad Saude Publica 2008, 24:2941-2947

302. Costa CH, Stewart JM, Gomes RB, Garcez LM, Ramos PK, Bozza M, Satoskar A, Dissanayake S, Santos RS, Silva MR, Shaw JJ, David JR, Maguire JH: Asymptomatic human carriers of Leishmania chagasi. Am J Trop Med Hyg 2002, 66:334-337.

303. Silveira FT, Lainson R, Crescente JA, de Souza AA, Campos MB, Gomes CM, Laurenti MD, Corbett CE: A prospective study on the dynamics of the clinical and immunological evolution of human Leishmania (L.) infantum chagasi infection in the Brazilian Amazon region. Trans $R$ Soc Trop Med Hyg 2010, 104:529-535.

304. Lima ID, Queiroz JW, Lacerda HG, Queiroz PV, Pontes NN, Barbosa JD, Martins DR, Weirather JL, Pearson RD, Wilson ME, Jeronimo SM: Leishmania infantum chagasi in northeastern Brazil: asymptomatic infection at the urban perimeter. Am J Trop Med Hyg 2012, 86:99-107.

305. Alvarenga DG, Escalda PM, Costa AS, Monreal MT: Visceral leishmaniasis: retrospective study on factors associated with lethality. Rev Soc Bras Med Trop 2010, 43:194-197.

306. Madalosso G, Fortaleza CM, Ribeiro AF, Cruz LL, Nogueira PA, Lindoso JA American visceral leishmaniasis: factors associated with lethality in the state of São Paulo, Brazil. J Trop Med 2012, 2012:281572.

307. Barata RA, Peixoto JC, Tanure A, Gomes ME, Apolinário EC, Bodevan EC, de Araújo HS, Dias ES, Pinheiro AC: Epidemiology of visceral leishmaniasis in a reemerging focus of intense transmission in Minas Gerais state, Brazil. Biomed Res Int 2013, 2013:405083.

308. Dubey JP, Lago EG, Gennari SM, Su C, Jones JL: Toxoplasmosis in humans and animals in Brazil: high prevalence, high burden of disease, and epidemiology. Parasitology 2012, 139:1375-1424
309. Ekman CC, Chiossi MF, Meireles LR, Andrade Júnior HF, Figueiredo WM, Marciano MA, Luna EJ: Case-control study of an outbreak of acute toxoplasmosis in an industrial plant in the state of São Paulo, Brazil. Rev Inst Med Trop Sao Paulo 2012, 54:239-244.

310. Xavier GA, Cademartori BG, Cunha Filho NA, Farias NA: Evaluation of seroepidemiological toxoplasmosis in HIV/AIDS patients in the south of Brazil. Rev Inst Med Trop Sao Paulo 2013, 55:25-30.

311. Hotez PJ, Dumonteil E, Heffernan MJ, Bottazzi ME: Innovation for the 'bottom 100 million': eliminating neglected tropical diseases in the Americas. Adv Exp Med Biol 2013, 764:1-12.

312. Coura JR, Dias JC: Epidemiology, control and surveillance of Chagas disease: 100 years after its discovery. Mem Inst Oswaldo Cruz 2009, 104(Suppl 1):31-40.

313. Deane LM: Animal reservoirs of Trypanosoma cruzi in Brazil. Rev Bras Malariol Doencas Trop 1964, 16:27-48.

314. Alencar JE, Almeida YM, Santos AR, Freitas LM: Epidemiology of Chagas' disease in the state of Ceará, Brazil. Rev Bras Malariol D Trop 1975, 26:5-26.

315. Mott KE, Mota EA, Sherlock I, Hoff R, Muniz TM, Oliveira TS, Draper CC: Trypanosoma cruzi infection in dogs and cats and household seroreactivity to T. cruzi in a rural community in northeast Brazil. Am J Trop Med Hyg 1978, 27:1123-1127.

316. Barrett TV, Hoff R, Mott KE, Guedes F, Sherlock IA: An outbreak of acute Chagas's disease in the São Francisco Valley region of Bahia, Brazil: triatomine vectors and animal reservoirs of Trypanosoma cruzi. Trans $R$ Soc Trop Med Hyg 1979, 73:703-709.

317. Maywald PG, Machado MI, Costa-Cruz JM, Gonçalves-Pires M: Leishmaniose tegumentar, visceral e doença de Chagas caninas em municípios do Triângulo Mineiro e Alto Paranaíba, Minas Gerais, Brasil. Cad Saude Publica 1996, 12:321-328.

318. Herrera L, D'Andrea PS, Xavier SC, Mangia RH, Fernandes O, Jansen AM: Trypanosoma cruzi infection in wild mammals of the National Park 'Serra da Capivara' and its surroundings (Piauí, Brazil), an area endemic for Chagas disease. Trans R Soc Trop Med Hyg 2005, 99:379-388.

319. Souza-Lima RD, Barbosa MD, Coura JR, Arcanjo AR, Nascimento AD, Ferreira JM, Magalhães LK, Albuquerque BC, Araújo GA, Guerra JA: Outbreak of acute Chagas disease associated with oral transmission in the Rio Negro region, Brazilian Amazon. Rev Soc Bras Med Trop 2013, 46:510-514.

320. Cerqueira EJ, Silva EM, Monte-Alegre AF, Sherlock IA: Notes on fleas (Siphonaptera) of the fox Cerdocyon thous (Canidae) from an endemic area of visceral leishmaniasis in Jacobina, Bahia, Brazil. Rev Soc Bras Med Trop 2000, 33:91-93.

321. Labruna MB, Jorge RS, Sana DA, Jácomo AT, Kashivakura CK, Furtado MM, Ferro C, Perez SA, Silveira L, Santos TS Jr, Marques SR, Morato RG, Nava A, Adania $\mathrm{CH}$, Teixeira RH, Gomes AA, Conforti VA, Azevedo FC, Prada CS, Silva JC, Batista AF, Marvulo MF, Morato RL, Alho CJ, Pinter A, Ferreira PM, Ferreira F, Barros-Battesti DM: Ticks (Acari: Ixodida) on wild carnivores in Brazil. Exp Appl Acarol 2005, 36:149-163.

322. Dantas-Torres F, Ferreira DR, Melo LM, Lima PA, Siqueira DB, Rameh-deAlbuquerque LC, de Melo AV, Ramos JA: Ticks on captive and free-living wild animals in northeastern Brazil. Exp Appl Acarol 2010, 50:181-189.

323. Martins JR, Reck J Jr, Doyle RL, Cruz NL, Vieira AW, Souza UA: Amblyomma aureolatum (Acari: Ixodidae) parasitizing margay (Leopardus wiedii) in Rio Grande do Sul. Rev Bras Parasitol Vet 2010, 19:189-191.

324. Ruas JL, Muller G, Farias NA, Gallina T, Lucas AS, Pappen FG, Sinkoc AL Brum JG: Helminths of Pampas fox, Pseudalopex gymnocercus (Fischer, 1814) and of Crab-eating fox, Cerdocyon thous (Linnaeus, 1766) in the South of the State of Rio Grande do Sul, Brazil. Rev Bras Parasitol Vet 2008, $17: 87-92$.

325. Ribeiro CT, Verocai GG, Tavares LE: Dioctophyme renale (Nematoda, Dioctophymatidae) infection in the crab-eating fox (Cerdocyon thous) from Brazil. J Wildl Dis 2009, 45:248-250.

326. Vieira FM, Luque JL, Lima SS, Neto AH, Muniz-Pereira LC: Dipylidium caninum (Cyclophyllidea, Dipylidiidae) in a wild carnivore from Brazil. J Wildl Dis 2012, 48:233-234.

327. Megid J, de Souza VA, Teixeira CR, Cortez A, Amorin RL, Heinemman MB, Cagnini DQ, Richtzenhain $\sqcup$ : Canine distemper virus in a crab-eating fox (Cerdocyon thous) in Brazil: case report and phylogenetic analyses. J Wildl Dis 2009, 45:527-530.

328. Megid J, Teixeira CR, Amorin RL, Cortez A, Heinemann MB, Antunes JMP, Costa LF, Fornazari F, Cipriano JR, Cremasco A, Richtzenhain LJ: First identification of canine distemper virus in hoary fox (Lycalopex vetulus): pathologic aspects and virus phylogeny. J Wildl Dis 2010, 46:303-305. 
329. Luppi MM, Malta MC, Silva TM, Silva FL, Motta RO, Miranda I, Ecco R, Santos RL: Visceral leishmaniasis in captive wild canids in Brazil. Vet Parasitol 2008, 155:146-151.

330. Vieira FM, Luque JL, Muniz-Pereira LC: Checklist of helminth parasites in wild carnivore mammals from Brazil. Zootaxa 2008, 1721:1-23.

331. Soares RM, Cortez LR, Gennari SM, Sercundes MK, Keid LB, Pena HF: Crab-eating fox (Cerdocyon thous), a South American canid, as a definitive host for Hammondia heydorni. Vet Parasitol 2009, 162:46-50

332. Tenório MS, Oliveira e Sousa L, Paixão MS, Alves MF, Paulan SC, Lima FL, Jusi MM, Tasca Kl, Machado RZ, Starke-Buzetti WA: Visceral leishmaniasis in a captive crab-eating fox Cerdocyon thous. J Zoo Wildl Med 2011, 42:608-616.

333. Almeida Curi NH, Coelho CM, de Campos Cordeiro Malta M, Magni EM, Sábato MA, Araújo AS, Lobato ZI, Santos JL, Santos HA, Ragozo AA, de Souza SL: Pathogens of wild maned wolves (Chrysocyon brachyurus) in Brazil. J Wildl Dis 2012, 48:1052-1056.

334. da Agricultura M: Pecuária e Abastecimento: Legislação relacionada aos produtos de uso veterinário. Brasília: MAPA/ACS; 2012.

335. Forlano M, Scofield A, Elisei C, Fernandes KR, Ewing SA, Massard CL: Diagnosis of Hepatozoon spp. in Amblyomma ovale and its experimental transmission in domestic dogs in Brazil. Vet Parasitol 2005, 134:1-7.

336. Rubini AS, Paduan KS, Martins TF, Labruna MB, O'Dwyer LH: Acquisition and transmission of Hepatozoon canis (Apicomplexa: Hepatozoidae) by the tick Amblyomma ovale (Acari: Ixodidae). Vet Parasitol 2009, 164:324-327.

337. de Miranda RL, de Castro JR, Olegário MM, Beletti ME, Mundim AV, O'Dwyer LH, Eyal O, Talmi-Frank D, Cury MC, Baneth G: Oocysts of Hepatozoon canis in Rhipicephalus (Boophilus) microplus collected from a naturally infected dog. Vet Parasitol 2011, 177:392-396.

338. Almeida GLG, Vicente JJ: Cercopithifilaria bainae sp. n. parasita de Canis familiaris (L.) (Nematoda, Filarioidea). Atas Soc Biol Rio de Janeiro 1984, 24:18.

339. Otranto D, Brianti E, Latrofa MS, Annoscia G, Weigl S, Lia RP, Gaglio G, Napoli E, Giannetto S, Papadopoulos E, Mirò G, Dantas-Torres F, Bain O: On a Cercopithifilaria sp. transmitted by Rhipicephalus sanguineus: a neglected, but widespread filarioid of dogs. Parasit Vectors 2012, 5:1.

340. Otranto D, Varcasia A, Solinas C, Scala A, Brianti E, Dantas-Torres F, Annoscia G, Martin C, Mutafchiev Y, Bain O: Redescription of Cercopithifilaria bainae Almeida \& Vicente, 1984 (Spirurida, Onchocercidae) from a dog in Sardinia, Italy. Parasit Vectors 2013, 6:132.

341. Latrofa MS, Dantas-Torres F, Annoscia G, Cantacessi C, Otranto D: Comparative analyses of mitochondrial and nuclear genetic markers for the molecular identification of Rhipicephalus spp. Infect Genet Evol. in press.

342. Jefferies R, Shaw SE, Viney ME, Morgan ER: Angiostrongylus vasorum from South America and Europe represent distinct lineages. Parasitology 2009, 136:107-115.

343. Marcondes M, de Lima VM, de Araújo MD, Hiramoto RM, Tolezano JE, Vieira RF, Biondo AW: Longitudinal analysis of serological tests officially adopted by the Brazilian Ministry of Health for the diagnosis of canine visceral leishmaniasis in dogs vaccinated with Leishmune ${ }^{\oplus}$. Vet Parasitol 2013, 197:649-652

344. Franken AMJ, Figueiredo MJ, Coutinho SG: Prevalência de Isospora em cães de diferentes áreas da cidade do Rio de Janeiro. Rev Soc Bras Med Trop 1975, 9:45-51.

345. Ogassawara S, Larsson CE, Larsson MHMA, Hagiwara MK: Incidence of Isospora sp. in dog of the city of São Paulo. Rev Fac Med Vet Zootec Univ S Paulo 1978, 15:137-142

346. Pena HF, Ogassawara S, Sinhorini IL: Occurrence of cattle Sarcocystis species in raw kibbe from Arabian food establishments in the city of São Paulo, Brazil, and experimental transmission to humans. J Parasitol 2001 87:1459-1465

347. Ruas JL, Cunha CW, Silva SS: Prevalência de Sarcocystis spp. (Lankester, 1882) em bovinos clinicamente sadios, da Região Sul do Rio Grande do Sul, Brasil. Rev Bras Agrociência 2001, 7:227-230.

348. Lopes CW, de Sá WF, Botelho GG: Lesions in cross-breed pregnant cows, experimentally infected with Sarcocystis cruzi (Hasselmann, Wenyon, 1926 (Apicomplexa: Sarcocytidae). Rev Bras Parasitol Vet 1923, 2005(14):79-83.

349. Funada MR, Pena HFJ, Soares RM, Amaku M, Gennari SM: Frequency of gastrointestinal parasites in dogs and cats referred to a veterinary school hospital in the city of São Paulo. Arq Bras Med Vet Zootec 2007, 59:1338-1340.

350. Santos FAG, Yamamura MH, Vidotto O, Camargo PL: Occurrence of gastrointestinal parasites in dogs (Canis familiaris) with acute diarrhea from metropolitan region of Londrina, Parana State, Brazil. Semina: Ciências Agrárias 2007, 28:257-268.

351. Silva RC, Su C, Langoni H: First identification of Sarcocystis tenella (Railliet, Moulé, 1886 (Protozoa: Apicomplexa) by PCR in naturally infected sheep from Brazil. Vet Parasitol 1886, 2009(165):332-336.

352. Monteiro RM, Richtzenhain LJ, Pena HF, Souza SL, Funada MR, Gennari SM, Dubey JP, Sreekumar C, Keid LB, Soares RM: Molecular phylogenetic analysis in Hammondia-like organisms based on partial Hsp70 coding sequences. Parasitology 2007, 134:1195-1203.

353. Coelho WMD, Amarante AFT, Perri SHV, Coelho NMD, Apolinário JC, Teixeira WFP, Brescian KDS: Coccidiosis in dogs and cats at the municipality of Andradina in the State of São Paulo, Brazil. Braz J Vet Res Anim Sci 2012, 49:162-166.

354. Ragozo AMA, Muradian V, Silva JCR, Caravieri R, Amajoner VR, Magnabosco C, Gennari SM: Occurrence of gastrointestinal parasites in feces of cats from the cities of São Paulo and Guarulhos. Braz J Vet Res Anim Sci 2002 39:244-246.

355. Nery-Guimarães F, Lage HA: Prevalence and intestinal cycle of Isospora felis Wenyon, 1923 e I. rivolta (Grassi, Wenyon, 1923 in the domestic cat. Mem Inst Oswaldo Cruz 1879, 1973(71):43-54.

356. Togni M, Panziera W, Souza TM, Oliveira Filho JC, Mazzanti A, Barros CSL, Fighera RA: Aspectos epidemiológicos, clínicos e anatomopatológicos da infecção por Gurltia paralysans em gatos. Pesq Vet Bras 2013, 33:363-371.

doi:10.1186/1756-3305-7-22

Cite this article as: Dantas-Torres and Otranto: Dogs, cats, parasites, and humans in Brazil: opening the black box. Parasites \& Vectors 2014 7:22.

\section{Submit your next manuscript to BioMed Central and take full advantage of:}

- Convenient online submission

- Thorough peer review

- No space constraints or color figure charges

- Immediate publication on acceptance

- Inclusion in PubMed, CAS, Scopus and Google Scholar

- Research which is freely available for redistribution 